\title{
A Stranger in a Strange Land: Magical Thinking in the Fiction of Alistair MacLeod.
}

\author{
By
}

Joseph V. Palmer, B.A.

A thesis submitted to the Faculty of Graduate Studies and Research in partial fulfillment of the requirements for the degree of Master of Arts.

Department of English Language and Literature

\author{
Carleton University \\ Ottawa, Ontario
}

September 2, 2005

Copyright 2005, Joseph Palmer 


$\begin{array}{ll}\begin{array}{l}\text { Library and } \\ \text { Archives Canada }\end{array} & \begin{array}{l}\text { Bibliothèque et } \\ \text { Archives Canada }\end{array} \\ \begin{array}{l}\text { Published Heritage } \\ \text { Branch }\end{array} & \begin{array}{l}\text { Direction du } \\ \text { Patrimoine de l'édition }\end{array} \\ \begin{array}{l}\text { 395 Wellington Street } \\ \text { Ottawa ON K1A ON4 }\end{array} & \begin{array}{l}\text { 395, rue Wellington } \\ \text { Ottawa ON K1A ON4 } \\ \text { Canada }\end{array}\end{array}$

Your file Votre référence

ISBN: 0-494-10067-2

Ourfile Notre référence

ISBN: 0-494-10067-2

NOTICE:

The author has granted a nonexclusive license allowing Library and Archives Canada to reproduce, publish, archive, preserve, conserve, communicate to the public by telecommunication or on the Internet, loan, distribute and sell theses worldwide, for commercial or noncommercial purposes, in microform, paper, electronic and/or any other formats.

The author retains copyright ownership and moral rights in this thesis. Neither the thesis nor substantial extracts from it may be printed or otherwise reproduced without the author's permission.
AVIS:

L'auteur a accordé une licence non exclusive permettant à la Bibliothèque et Archives Canada de reproduire, publier, archiver, sauvegarder, conserver, transmettre au public par télécommunication ou par l'Internet, prêter, distribuer et vendre des thèses partout dans le monde, à des fins commerciales ou autres, sur support microforme, papier, électronique et/ou autres formats.

L'auteur conserve la propriété du droit d'auteur et des droits moraux qui protège cette thèse. $\mathrm{Ni}$ la thèse ni des extraits substantiels de celle-ci ne doivent être imprimés ou autrement reproduits sans son autorisation.
In compliance with the Canadian

Privacy Act some supporting forms may have been removed from this thesis.

While these forms may be included in the document page count, their removal does not represent any loss of content from the thesis.
Conformément à la loi canadienne sur la protection de la vie privée, quelques formulaires secondaires ont été enlevés de cette thèse.

Bien que ces formulaires aient inclus dans la pagination, il n'y aura aucun contenu manquant.

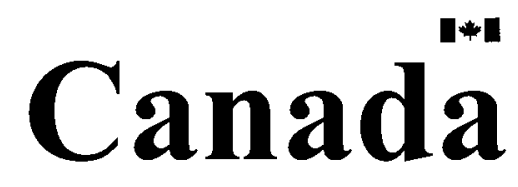




\section{Abstract}

This thesis demonstrates how Alistair MacLeod combines realist and romantic elements in both his short fiction collection Island, as well as the novel No Great Mischief. The social conditions in which his characters live are woven together with some of the region's folklore and magical beliefs. In MacLeod's work, magical thinking influences the behaviour of his characters: a supernatural phenomenon, such as ghosts, can bring them closer to their history, while their tendency to animate features of the landscape illustrates how the magical can mediate between them and their geography. Through the figure of the outsider, MacLeod is able to address the issues surrounding foreign influences in Cape Breton communities, issues such as the loss of economic, political, and cultural autonomy. The figure of the outsider also serves as a catalyst, triggering the kind of concerns for pollution that Mary Douglas wrote about in her book Purity and Danger, which involve magical thinking as well. Globalization, a process that makes contact with outsiders unavoidable, threatens to destroy the magical by eroding local culture through excessive commercialization and out-migration. 


\section{Acknowledgements}

I am indebted to Linda Woodbridge and her book The Scythe of Saturn: Shakespeare and Magical Thinking, which has been invaluable as a source of inspiration in the construction of a methodology.

Special thanks to Parker Duchemin, whose supervision and friendship made all the difference 
"An ancient chill is rippling the dark brooks."

Elizabeth Bishop 


\section{Table of Contents}

$\begin{array}{ll}\text { Introduction } & 1\end{array}$

Island

$1968-1976$

11

1976-1986

40

1988-1999

63

No Great Mischief

71

Conclusion

89

Bibliography

93 


\section{Introduction}

The title of this paper, A Stranger in a Strange Land, is in fact a passage from the Book of Exodus. They are the words that Moses uses to describe himself to Jethro, the priest of Madian. To Jethro, his status as a stranger was inconsequential but to Moses and his people, the Hebrews, a stranger in one's midst was a serious matter. Such a person was considered a potential threat to the community. The crossing of such a social boundary could lead to intense anxiety among community members, anxiety that could surface as concern for bodily pollution (Douglas 30 ). For reasons that will become apparent, the excerpt is a fitting point from which to jump into an examination of the fiction of Alistair MacLeod.

At the hands of critics and academics alike, Atlantic Canadian fiction has undergone a great deal of analysis. Some, like David Creelman and Janice Kulyk Keefer, have pointed out a number of important themes and characteristics common to the work of a wide variety of Maritime writers. According to them, the figure of the outsider and themes such as leaving or returning appear in the literature throughout the Atlantic region, and they reflect a common concern for community. Folklore and magic, too, are omnipresent but they are rarely treated as anything more than a sideshow attraction, a curious feature of the writing but one that hardly merits deeper analysis. Few analysts, if any, have explored the purposes to which writers have applied magic and folklore in their work or how these may relate to regional themes.

Although he was born in North Battleford, Saskatchewan, Alistair MacLeod has lived much of his life in Inverness County, Cape Breton, among his extended family. His ancestors were among the many Highlanders, forcibly removed from their ancestral lands during the 
Scottish clearances, only to make a new home for themselves on the shores of Eastern Canada. In the isolated communities of the Cape Breton Highlands, the Gaelic language and traditions remained relatively unchanged until the middle of the twentieth century. The goal of this paper is to explore how it is that MacLeod has responded to the longstanding traditions in the region, firstly by identifying examples of magic and folklore, tracing their possible origins, and examining the ends to which they are used. MacLeod's depicts Cape Breton as a culture in the process of being displaced by the trend towards economic globalization. As a result, the region's magical traditions are threatened, and they are what connect the Highlanders to their history and geography in a meaningful way.

MacLeod's stories often resemble folktales in both content and structure. This is not surprising since he was greatly influenced by the repertoires of Cape Breton's storytellers. MacLeod has remarked how fortunate he was to have had access to the island's genuine oral traditions (Shaw, Every Song xii-xiii). In an interview with Craig McDonald, MacLeod said, "I'm one of those writers who believes storytelling is older than literacy and I think of myself as a storyteller." (McDonald 7). One personality who had an influence on a younger MacLeod was the Cape Breton storyteller Lauchie MacLellan. During his young manhood, MacLellan lived only two miles from where MacLeod grew up and spent a number of summers at the Macleod home working as a handyman (Shaw, Every Song xi). Alistair MacLeod attended the same schoolhouse as MacLellan's children and his wife sang with MacLellan in the Gaelic group Coisir an Eileann (Shaw, Every Song xi). MacLeod has this to say of Lauchie MacLellan: Sometimes on summer Sunday afternoons he would come "to visit," bringing with him Gaelic texts and transcripts of certain songs that he had discovered or rediscovered and which he felt were worthy of discussion and inclusion. My wife 
shared his enthusiasm if not his vast knowledge. She was also a MacLellan by birth and they shared a common Morar history. (Shaw, Every Song xii)

MacLeod was deeply impressed with the vast knowledge of his friend, a resource he would draw upon in constructing his own stories.

MacLellan's family arrived in Broad Cove on the western shore of Cape Breton in 1820 having departed the region of Morar, Scotland, a few years earlier (Shaw, Every Song 5). They had a history as storytellers even before their arrival in the new world but there is no documented evidence to corroborate claims that his material does indeed originate in Morar. Unlike some other regions, little of the Morar tradition has survived. However, comparisons between MacLellan's material and that of other families with Morar roots support the belief that many of MacLellan's songs did originate in the region during the nineteenth century (Shaw, Every Song xxii). A manuscript containing material originally belonging to MacLellan's greatgrandfather has survived, revealing that there had been very few changes through the years (Shaw, Every Song xxii)

MacLeod's stories, like MacLellan's tales, tend to focus on history and the supernatural. In MacLeod's writing, the supernatural has the effect of enriching his character's connection to his geography. This supernatural relationship to geography is frequently depicted in a sexual manner: a character's decision to leave or to stay in Cape Breton is often determined by his libido. MacLeod's characters and their ancestors have occupied the same location for so long that they have begun to mystify their relationship with the land. At times, they seem to be caught in its grip as though the land had a will of its own, often exercising a powerful, sometimes malevolent, hold over them. This is a sign of animism, the attribution of soul or spirit to living or inanimate 
objects. Such behaviour suggests participation, the mystical belief that everything and everyone form a part of each other (Zusne 26).

The use of folklore and magic of course did not begin with MacLeod. Magical thinking first surfaced in the Atlantic Canadian literature during the nineteenth century and continued to be a feature of the writing down to the present day. As far back as Thomas Haliburton's The Clockmaker (1835), themes like that of the outsider have appeared in the region's literature (Keefer, Eastern Eyes 45). A deliberate effort to include magic and folklore in the region's writing began in the nineteen twenties and thirties with the work of Frank Parker Day and "The Song Fisherman." Their efforts were part of a movement to create a body of work that was uniquely Maritime (Davies 164). More recently, the writer D.R. MacDonald also included the figure of the outsider in his short stories. In his book Setting in the East: Maritime Realist Fiction (2003), Creelman explains how there are two main streams that run through much of Atlantic Canadian fiction, realism and romanticism. MacLeod merges these two streams together with his treatment of the figure of the outsider.

Originally, magical thinking evolved as a method of nature-based problem solving. That is to say, it took its cue from the "observed regularities in natural phenomena, of laws of nature" (Zusne 14). Magical thinking often reflected anxieties that were agrarian in nature, such as the concerns over fertility, infestation, and pollution. For example, crops meant to sustain a community could be lost by the accidental introduction of disease, and livestock might become weakened by uncontrolled fertilization from wild or questionable stock. In The Golden Bough: A Study in Magic and Religion (1890), Sir James George Frazer defined contagion as the belief that anything which comes into contact with a person, animal or object acquires its source of power, whether negative or positive (Frazer Vol 1. 52). Frazer's work made one thing perfectly 
clear: early societies experienced a great deal of anxiety regarding contact with outsiders. There was good reason to be cautious; disease could threaten a community's socio-economic stability, not to mention the lives of its members. Just as serious as the physical threat was the possibility of psychological contamination: new ideas could destabilize the balance of a community's existing ideology. How the transgression of social barriers was related to fears of bodily pollution was not fully understood until the anthropologist Mary Douglas published her book Purity and Danger: An Analysis of Concepts of Pollution and Taboo (1966). Douglas, however, argued that medical materialism was not likely the cause of pollution anxiety. In her opinion, hygiene could be divorced from pollution theory because early peoples were not aware of microbic infection or parasites. The anxiety associated with dirt was a matter of disorder and not disease. Anything anomalous or ambiguous could trigger such a response. Her theories on pollution associated with boundary crossings figure prominently in MacLeod's work. Fear of the outsider on the part of MacLeod's characters often coincide with pollution fears: traditional Highland culture is frequently depicted as having been poisoned or polluted by the outside world, and characters are concerned about sexual transgressions. In her book Under Eastern Eyes: A Critical Reading of Maritime Fiction (1987), Janice Kulyk Keefer points out that the outsider and themes common to Atlantic Canadian literature, such as leaving and returning, all demonstrate a concern for community integrity (Keefer, Eastern Eyes 39). Specifically, they demonstrate an awareness of an intensifying process of cultural disintegration.

MacLeod's fiction also touches upon the psychological processes. Magical thinking is part of a human being's cognitive development; beginning in infancy, it reflects an inner need for simple but potent solutions. Psychologist Jean Piaget studied child behaviour and concluded that magical thinking was an essential stage in early development. In 1959, Iona and Peter Opie 
published The Lore and Language of Schoolchildren, which sketched out a detailed picture of the child's world: their rhymes, songs, riddles, games and customs. Many of them involved definite forms of magical thinking. The simplest and most common of those involved ritual gestures such as the shaking of hands, crossing one's heart, touching inanimate objects or objects of religious significance (Vyse 142). Touching such objects implies that one can acquire its power. This is a form of simple causal reasoning, typical of magical thinking. Pollution fears operate in a similar manner.

In his book Believing in Magic: The Psychology of Superstition (1997), Stuart Vyse noted the amazing similarities between childhood superstitions and those of adults, implying that magical thinking may not be entirely abandoned with the onset of adulthood. Once established, magical beliefs are passed on from parent to child by way of internalization, a term used to describe the process by which children adopt or consent to the general orientation of their parents (Zusne 250). Vyse accumulated a vast amount of data on the superstitious practices of Americans from a wide range of backgrounds: good-luck talismans such as a rabbit's foot or a four-leaf clover are perfect examples of modern attempts to control random events. Superstitious behaviour abounds even in relatively rational institutions like universities. Many students he interviewed wore "magical garb" such as lucky sweaters into their exams (Vyse 35). The work of researchers like Vyse substantiate claims that magical thinking may still be observed in contemporary societies.

In their book Anomalistic Psychology: A Study of Magical Thinking (1989), Leonard Zusne and Warren Jones define magical thinking as the belief that the transfer of energy or information between physical systems may take place solely because of their similarity or contiguity in time and space or that one's thoughts words or actions can achieve specific 
physical effects in a manner not governed by the principles of modern physics (Zusne 13). Their definition relies on research conducted during the last century, beginning with Alfred Lehman Lehman was the first to have applied the scientific method to the study of magic. In his book Superstition and Magic (1893), he claimed that belief in the supernatural and the paranormal among rural people was a remnant of a pre-industrial ethos (Zusne 13). These people continued to think of events in simple causal relationships, which predated scientific rationalism. His work was not intended to be a derogatory critique of rural populations; he found similar practices among urbanites as well (Zusne 13).

With the sophisticated fieldwork of Bronislav Malinowski, the study of magic underwent a resurgence (Vyse 10-11). Malinowski documented a variety of magic rituals from sea-faring cultures and realized that magic was applied only as a last resort, when no other precaution could assure safety. Uncertainty, as a precondition to magical behaviour, became one of Malinowski's greatest contributions to the study of magic. The principle of uncertainty lies behind MacLeod's extensive use of magic and folklore, and implies that these are not quaint topics of conversation but genuine features of Highland culture, as genuine as the economic factors now threatening that culture. MacLeod relies on folklore and residual magical thinking to convey insights into the culture of Cape Breton. The relative isolation of the island until the twentieth century and the uncertainty of a life dependent on the land and sea provided an impetus for the survival of superstitious practices.

In his book Images of Savages: Ancient Roots of Modern Prejudice in Western Culture (1999), Gustav Jahoda suggests that it is part of the enduring tradition of Western science to view pre-industrial societies as backward and the European industrialized nations as advanced and innately superior. Therefore, Western idiosyncrasies such as the belief in superstition tend to 
be glossed over. In his opinion, the belief in paranormal phenomena in the industrialized West is equivalent to the superstitious practices of so-called "primitive" cultures. Magical thinking seemed to be a feature common to societies at various levels of development. Although magical thinking has its roots in early childhood development, it does not end there but continues to influence adult decision making even in modern technological societies.

In the case of MacLeod's work, folklore and the oral tradition have been critical in preserving patterns of magical thinking. Even in those communities where the text has surpassed the spoken word in importance, fiction continues to propagate notions of the magical. In Magical Thought in Creative Writing: The Distinctive Roles of Fantasy and Imagination in Fiction (1983), Anne Wilson explores the possible connections between magical thinking and Western literature. She claimed that, from Chaucer to Tolkien, there is an unmistakable connection between creative writing and magical thinking. These writers were well aware of the magical formulations within their work but were simply unconcerned with obvious lapses of reason knowing that their audiences, like themselves, had no difficulty in recognizing the patterns of magic particular to their culture (Wilson 9). Wilson implied that these writers partially understood the role of the magical mind and put it to use in the creative process. Aside from local folktales, MacLeod would have found a plentiful source of magical thinking in the English literary tradition. Some of the examples of magical thinking found in MacLeod's work are standard features in western literature, such as the symbolic coordination of plot with the seasons of the year, or the pairing of a character's moods with weather conditions.

It is magic and folklore, however, that form a part of MacLeod's unique historicism, conveying a sense of time so deep and so vast as to seem almost mythical. The omnipresence of history and folklore in his characters lives brings the past a little closer to the present. 
Meanwhile, the supernatural often serves as a tangible link between his characters and their ancestors. For example, ghosts may appear to characters, bridging the gap between generations. Characters may possess paranormal abilities like their distant ancestors, and their lives, therefore, become a recent chapter in the folkloric history of the Highlanders. In this way, the past remains a living force in the lives of the characters.

In addition, MacLeod renders the encroachment of urbanism and technology into Cape Breton as a break or negation of this meaningful connection to the Highlands. Throughout his work, there is a definite connection between the impact of globalization on Cape Breton and the decay of family lines and regional traditions. Like traditional European folktales, the kind that are found in children's collections, his stories warn against straying too far from home and caution readers of the danger strangers (outsiders) pose to the local community. Folk and fairy tales of this nature tend toward conservatism and cultural paternalism: they warn against straying outside societal boundaries. In the case of MacLeod's Highland characters, the anxiety they experience when confronting outsiders seems justified. For over two centuries, the Highlanders have endured the harsh conditions of Cape Breton Island and managed to preserve their traditions, that is until the middle of the twentieth century. The loss of economic autonomy to distant authorities and the out-migration of the island's population are eroding Highland culture. MacLeod's fiction suggests that the invasive and disruptive nature of federalism and globalization warrants this concern for the integrity of Gaelic traditions. The local folktales, having made their way into contemporary literature, also emphasized the importance of preserving history and traditional community values. It is not surprising that geography and community should play an important role in the work of various Cape Breton writers including MacLeod. Characters are concerned about the integrity of Highland culture, and the metaphors 
MacLeod uses to convey this concern also suggests that the Highlanders connection to the land is close to indigenous. In this case, indigenous means that his characters have achieved a kind of harmony with the land, an ecological balance (MacLeod, Island 153).

The clash between Cape Breton and the outside world in the region's fiction highlights the way in which urbanism and global economics can divest regional cultures of their distinctiveness. The arrival of urban technological society threatens to destroy the rural, partially magical culture of Cape Breton. Atlantic Canada has been experiencing socio-economic tensions since the early part of the nineteenth century. There are real economic and social factors influencing the region that appear in MacLeod's work. At times, many characters experience a good deal of anxiety over a culture seemingly in disintegration. In the region's literature, magic also tends to throw a light on the real conditions of the region and its people. Here, magic is not fantastical, but an essential aspect of the culture and an effective measure of the depths to which Cape Breton writers feel the crisis wrought by globalization. 


\section{$\underline{\text { Island }}$}

$\underline{1968-1976}$

Alistair MacLeod's short fiction collections Lost Salt Gift of Blood (1976), and As Birds Bring Forth the Sun (1986), have now been brought together into one book, Island (2000). It contains all sixteen of MacLeod's short stories arranged chronologically; two of them, "Island" and "Clearances," were previously uncollected. Throughout his stories, MacLeod explains how the Highlanders' relationship to geography has changed with the encroachment of modernity into Cape Breton. Collapsed fisheries and closed mines have forced the rural population to seek work abroad while affluent outsiders have flocked to the island to purchase the traditional homesteads. The changes wrought by the outsiders threaten this centuries old culture, and the characters in MacLeod's stories offer the reader a personal perspective into this recent version of the Highland clearances.

His characters respond to out-migration and cultural disintegration in a manner consistent with what Mary Douglas observed in earlier cultures. In Purity and Danger, she writes that pollution anxieties reflect a concern for the social order. Contamination or pollution could result from coming into contact with that which exists on the margins of order. One who comes into contact with such things risks acquiring its power, whether positive or negative. Outsiders cross social boundaries and contact with them means running the risk of pollution: "But the society does not exist in a neutral, unchanged vacuum. It is subject to external pressures; that which is not with it, part of it and subject to its laws, is potentially against it." She continues, “... I 
believe that ideas about separating, purifying, demarcating and punishing transgressions have as their main function to impose system on an inherently untidy experience." (Douglas 3-4) Recognizing bodily pollution or sexual transgressions are a response to perceived violations of social boundaries. In the case of MacLeod's characters, their pollution fears may be prompted by the fact that their culture is changing and it is the outsider that is the agent of change.

The earliest of MacLeod's stories, "The Boat" (1968), was first published in The Massachusetts Review and begins, as his stories often do, with a male narrator looking back on his childhood in Cape Breton. In this story, he is a professor at a Midwestern university, who still wakes at 4:00 am, as he did when he was a boy, answering his father's call to the boat. He remembers his father being a reluctant fisherman, born to a life he did not love. Even his flesh seemed to rebel against his lifestyle: his pink skin burns, never browns, and he is plagued with salt-water boils (MacLeod, Island 20). In his youth, he longed to attend university. Instead, he settled for his private room stuffed with an assortment of reading material.

His wife, once a local beauty, comes from a family with a long history of seamanship, and she is fiercely proud of her culture. Faced with the uncertainty that comes with a culture in transition, she clings to her traditions. She watches as her daughters leave home for the more exotic places on the mainland:

One by one they went. My mother had each of her daughters for fifteen years, then lost them for two and finally forever. None married a fisherman. My mother never accepted any of the young men, for in her eyes they seemed always a combination of the lazy, the effeminate, the dishonest and the unknown. They never seem to do any physical work and she could not comprehend their luxurious vacations and she did not known whence they came and who they were. 
And in the end she did not really care, for they were not of her people and they were not of her sea. (MacLeod, Island 16)

The words "they were not of her people" are explicit: her daughter's boyfriends are outsiders, and their presence in the community seems to her to be an invasion of all that is weak and undesirable. They are "the lazy, the effeminate, the dishonest and the unknown," loathsome qualities to those, like her, scratching out a living in a resource-based economy.

These are also qualities associated with a modern, urban lifestyle. The mainland's economy and institutions have become a threat. For example, a seafood restaurant franchise has opened in the community, which, coincidentally, is where her daughters end up working:

The restaurant was run by a big American concern from Boston and catered to the tourists that flooded the area in July and August. My mother despised the whole operation. She said the restaurant was not run by "our people," and "our people" did not eat there, and that it was run by outsiders for outsiders. (MacLeod, Island 10)

The regional economies increasingly feel the pressure of globalization. In the case of Cape Breton, traditional occupations such as mining and fishing, once the exclusive domain of men, are being replaced by non-traditional ones into which women can more easily move (Lewellen 36). Globalization, the loss of traditional values, and the feminization of Cape Breton society go hand in hand in MacLeod's stories. Certainly, there are pressing concerns prompting the mother's isolationist impulses. Her trouble is not just with outsiders who have come to her community, altering the landscape and culture, but also with her own family, her husband, and daughters who are influenced by these institutions and the outside ideas they bring with them. 
This is symbolized by the father's room, mentioned above, which is both a sanctuary for him, and a colony for outside ideas:

By about the ninth or tenth grade my sisters one by one discovered my father's bedroom, and then the change would begin.[...] My mother's reaction was always abrupt, bordering on the angry. "Take your nose out of that trash and come do your work," she would say, and once I saw her slap my younger sister so hard that the print of her hand was scarletly emblazoned on her daughter's cheek while the broken-spined paperback fluttered uselessly to the floor. (MacLeod, Island 9-10)

MacLeod partially associates education with the tendency for young people to leave the island, a situation with which he himself would be all too familiar. The room is the intellectual centre of the household, the place where the daughters are introduced to the world and acquire their father's desire to leave. It is also the focus of their mother's disdain: she sees it and its books as a threat to all she values.

Especially poignant is the mother's choice of the word "effeminate" to describe these young men. True, compared to the rugged fishermen they must seem soft, but perhaps there is more to it than that. MacLeod's male characters often wrestle with questions regarding their identity. There is something about urbanism that is emasculating. The traditional Highland culture encounters the modern world and as a result experiences a loss of traditional values, which leads to confusion on behalf of the men as to what constitutes the male identity. Their loss of confidence in traditional gender roles translates into a loss of essence or virility; the women in this society fill in the vacuum left behind by these men. That is why there are such strong, 
protective female characters in MacLeod's work. The story "The Boat" is a perfect example of this: although the father is the provider, he is by no means the strongest character:

When he came home he threw the money he had earned on the kitchen table as he did with all his earnings but my mother refused to touch it, and the next day he went with the rest of the men to bait his trawl in the shanties. The tourists came to the door that evening and my mother met them there and told them that her husband was not in, although he was lying in bed only a few feet away, with the radio playing and the cigarette upon his lips. She stood in the doorway until they reluctantly went away. (MacLeod, Island 14)

The way MacLeod has written this scene makes it especially poignant: the mother becomes a sentinel, standing guard between her family and outsiders like the tourists her husband takes out on the boat. Her role is to preserve the social order by protecting her family and community from outsiders. She is especially rigid when it comes to her daughter's boyfriends. The mother leaves little doubt as to the kind of threat that she imagines they pose:

"I don't know what's the matter with my girls. It seems none of them are interested in the right things." And sometimes there would be bitter savage arguments. One afternoon I was coming in with the mackerel I'd been given at the wharf when I heard her say, "Well, I hope you'll be satisfied when they come home knocked up and you'll have had your way." (MacLeod, Island 11)

In the opinion of the daughters, the men "from away" are preferable to local boys because they are exotic and carry with them the possibility of escape. The threat they pose to the community has been interpreted, by the mother, as a sexual transgression. According to Douglas, "Females are correctly seen as, literally, the entry by which the pure content may be adulterated." 
(Douglas 126). Guarding feminine virtue equates with protecting cultural integrity (Woodbridge 59-60)

One can find similar behaviour in some of the earlier literature from the region as well. In Frank Parker Day's novel Rockbound (1928), for example, the protagonist, David Jung, arrives on Rockbound only to find it ruled by a tyrannical figure named Gershom. David's welcome leaves much to be desired: even his distant relatives treat him as an outsider. The figure of the outsider, like the inclusion of folklore, is part of the Maritime literary tradition. In his book Setting in the East: Maritime Realist Fiction (2003), David Creelman states that "romanticism" in Maritime literature, characteristic of writers like MacLeod, began in the 1920's with works like Frank Parker Day's Rockbound and The Song Fisherman's Song Book (1928). According to Gwendolyn Davies, these "romantic" features were part of a deliberate effort to create something distinctly Eastern: "a Nova Scotian voice in poetry at the very time when rural values and the oral tradition were being eroded by out-migration,[...]" (Davies 164). Often praised for their realistic portrayal of Maritime life, they were also condemned for the inclusion of "crass" superstition (Davies 186). At the time, few critics understood the significance of folklore and superstition in Atlantic Canadian literature. More than a quaint regional distraction, folklore and the figure of the outsider offer the reader an insight into the collective psyche of the people. In Bluenose Ghosts, Helen Creighton states that superstition, so much a part of local folklore, is not merely entertainment for Easterners (Creighton, Bluenose Ghosts 4).

In the short story "One of a Kind," D.R. MacDonald explores the exotic allure of the stranger, which he connects to the extravagant and excessive practices of those who live in New York City. Red Donald is a local handyman who is enamoured of his dead neighbour's wife: 
As he returned, she extracted a Rothman's and dangled it in the corner of her mouth. He liked that, something dangerous in that. But it was a city touch too and he felt the distance again, like someone stepping between them, someone he'd have to shove out of the way (MacDonald, Eyestone 182-183).

The outsider has a dual nature: he or she might be seen either as a predator, or as a tempter. This duality is not limited to the characters: The practices of the mainland economy, with its imported franchises, might seem predatorial, but as a source of employment, it is also a kind of tempter, luring the local youths away from Cape Breton. Like MacLeod, MacDonald joins the idea of alluring, sometimes dangerous, sexuality with the figure of the outsider. The reader's anxiety grows when he or she realizes that Red is a terribly lonely man, and Mrs. MacKay, although an outsider, is an extremely vulnerable woman: not only does she live alone but is nearly blind. When he realizes that he does not interest her, he attempts to inspire fear in her with local folklore. The Water-Horse has been known to spirit people away, he says. He also mentions how the trees on her property have grown closer to the house, giving the impression that the wilderness is slowly creeping in on her.

The emasculation of rural culture is evident in MacLeod's use of symbolism. The narrator in "The Boat" remembers how his father's body was found on the twenty-eighth of November, just ten miles north and wedged between two boulders in the cold Atlantic water:

His hands were shredded ribbons, as were his feet which had lost their boots to the suction of the sea, and his shoulders came apart in our hands when we tried to move him from the rocks. And the fish had eaten his testicles and the gulls had pecked out his eyes and the white-green stubble of his whiskers had continued to 
grow in death, like the grass on graves, upon the purple, bloated mass that was his face. (MacLeod, Island 25)

He describes his father's hands as shredded, his boots pulled away, and his reproductive organs as partially eaten. His hands and boots are the tools of his trade and symbolize his connection to the sea and local traditions. The consumption of his organs implies a loss of masculinity and virility. In addition, the death of the father means his son is unlikely to become a fisherman. The father would see this as a good thing: he did not wish this life for himself or his son. For the culture, so treasured by his wife, the break is tragic. MacLeod illustrates this with his depiction of the mother as the lonely sentinel of a dying culture:

And that she looks through her lonely window onto the ice of winter and the hot flat calm of summer and the rolling waves of fall. And that she lies awake in the early morning's darkness when the rubber boots of men scrunch upon the gravel as they pass beside her house on their way down to the wharf. And she knows that the footsteps never stop, because no man goes from her house, and she alone of all the Lynns has neither son nor son-in-law who walks towards the boat that will take him to the sea. (MacLeod, Island 25).

Later, the narrator describes how his father's fishing grounds have remained unused for the last ten years, which completes the break (MacLeod, Island 24).

In "The Vastness of the Dark" (1971), a young man named James leaves his Cape Breton home to work abroad. Alex deals with the troubling process of abandoning the only home he has ever known for an adult's world of earning a living. However, the local mines have closed and so he must head to the uranium mines of Blind River, Ontario, to find work. MacLeod deepens the sense of loss his protagonist feels when leaving home by expounding on their history and 
geographic connectedness. Even from the outset, MacLeod establishes that James is violating some kind of divine order: "“...I awake at exactly six a.m. to find myself on my eighteenth birthday, listening to the ringing of the bells from the Catholic Church which I now attend only reluctantly on Sundays. 'Well,' I say to the bells and to myself, 'at least tomorrow I will be free of you"” (MacLeod, Island 26).

The connection to geography that James's people have is so profound that it seems to acquire a supernatural quality; a mysterious, even malevolent, force appears to mediate between them and the landscape. MacLeod's characters have occupied the same place for generations, so it is not surprising to find a tendency to mystify their relationship to it or even animate features of the landscape. The narrator touches upon the mysterious power of the land when he recalls his grandfather's comment:

"Once you start, it takes a hold of you, once you drink underground water, you will always come back to drink some more. The water gets in your blood. It is in all of our blood. We have been working in the mines here since 1873." (MacLeod, Island 35)

There is a dark, perhaps sinister hold that the mine has over the miners. To imbibe the mine water is to ingest some of its power. It resembles the waters of forgetfulness in the Greek underworld. Those who drank it forgot their mortal lives and could never leave. In this case, MacLeod has borrowed from literary sources examples of magical relationships with the land. The grandfather's description of mine water is revealing: he believes that they have become contaminated by some power within the mine. Their connection to geography is not only physical, but magical, strengthening their ties to it and any indigenous claims as well. 
It is worth noting that the connection that the characters have with their geography has a distinctly sexual overtone. There is urgency in James's departure, spurred on by the eruption of his sexual libido. James realizes he must leave before his sexual desire ensnares him, like his father:

It seems to have come almost with the first waves of sexual desire and with it to have grown stronger and stronger with the passing months and years. For I must not become as my father whom I now hear banging the stove-lids below me as if there were some desperate rush about it all and some place that he must be in a very short time. Only to go nowhere. (MacLeod, Island 33)

There are indications that biology often betrays MacLeod's characters. The grandfather's confession to James that he was glad his father had gotten his mother pregnant is proof of this:

"You know," he said, "when I learned that your mother was knocked up I was so happy I was just ashamed. And my wife was in a rage and your mother's parents were weeping and wringing their silly hands and whenever I was near them I would walk around looking at my shoes. But I think that, God forgive me, I may have even prayed for something like that and when I heard it I said, 'Well, he will have to stay now and marry her because that's the kind of man he is, and he will work in my place now just as I've always wanted."' (MacLeod, Island 31) The fact that the grandfather "prayed" for such a thing gives the occasion an air of divine intervention. Prayers tend to fall under two categories: supplicatory and intercessory (Zusne 248). The first addresses a need and is an attempt at appeasement. The second attempts to intercede in the natural course of events to procure a desired end (Zusne 248). The grandfather's prayer has the mark of intercessory prayer. Frazer first distinguished prayer or supplication magic from 
sympathetic magic in The Golden Bough. The distinction may be purely cosmetic, however, an attempt to distinguish "civilized" beliefs from "primitive" ones (Zusne 249). Regardless, intercessory prayer is a form of magical thinking. When it is combined with the grandfather's earlier comment about mine water, they enhance the sense that some mysterious power intercedes in the lives of the characters. At the very least, one could argue that the grandfather's wish is a form of monoideistic desire, a desire that is itself connected to the occurrence of the event. Piaget saw this as participation (Zusne 28).

As he is leaving home, James makes a stop at "'over home," his grandparent's place. There he learns that his father once made the same journey he is about to make, as revealed in his letters to James's grandparents. This draws James's fate even closer to that of his father. Despite his efforts to leave, James fears that his attempts to escape will only serve to bring him under the influence of this malevolent force. He says: "I have been somehow apprehensive about even getting off Cape Breton Island, as if at the last moment it might extend gigantic tentacles, or huge monstrous hands like my grandfather's to seize and hold me back" (MacLeod, Island 45). In addition, no matter where the narrator goes, he encounters individuals, like himself, who are in the grip of hormonal forces, which in some way relates to geography. It is no accident that James ends up in the company of a sales clerk, who is motivated by his libido, as much as he is by economics.

The salesman James encounters is another example of the dangerous outsider. His honking the car horn and uttering lewd remarks reveal the kind of threat he poses:

My companion blasts out a rhythm of hornblasts at a young girl and her mother who are stretching up on their tiptoes to hang some washing on a clothesline. There is a basket of newly washed clothes on the ground between 
them and their hands are busy on the line. They have some clothes pins in their teeth so they will not have to bend to reach them and lose their hand-hold on the line.

"If I had my way, they'd have something better'n that in their mouths," he says "wouldn't mind resting my balls on the young one's chin for the second round." (MacLeod, Island 50)

Here is a modern, provocative reinvention of Thomas Haliburton's Sam Slick, one whose character has been given a sexual edge. Sam Slick is the earliest example of the outsider figure to appear in Atlantic Canadian literature (Keefer, Eastern Eyes 45). He originally appeared in a series of sketches titled The Clockmaker in the Nova Scotian from September 23, 1835 to February 11, 1836 (Parker xvii). Sam was a fast-talking American who managed to get the drop on naive locals. The clocks he sold were gaudy and cheap; it is his savvy salesmanship that makes them attractive. His industriousness belongs to the 'new man,' the American businessman, and he stands in sharp contrast to his conservative, slow-paced victims. His opportunistic, even predatory nature highlights the danger associated with the outsider. George L. Parker lists a variety of possible influences on Haliburton's construction of the character of Sam Slick: "Noctes Ambrosianae", an imaginary conversation on politics published in Blackwood's between 1822 and 1835, and Thomas McCulloch's The Mephibostheth Stepsure Letters (18211823) among others (Parker xxi). As a boy, Haliburton had witnessed some of the horrors of naval warfare during the War of 1812 . Such events must have had a profound effect on him, convincing Haliburton of the vulnerability of the Maritimes to foreign, particularly American, power and ideas (Parker xviii). 
James's companion leaves a marked impression on him. He recalls their conversation and his thoughts on the nature of the foreigner. The section draws the reader's attention to questions of cultural inclusion/exclusion:

For the man in whose glassed-in car I now sit sees only similarity. For him the people of this multi-scarred little town are reduced to but a few phrases and the act of sexual intercourse. They are only so many identical goldfish leading identical, incomprehensible lives within the glass prison of their bowl. And the people in the street view me behind my own glass in much the same way, and it is the way that I have looked at others in their 'foreign licence' cars, and it is the kind of judgement I myself have made. (MacLeod, Island 56)

Being away from home has given James the opportunity to reconsider his opinion of outsiders. In a way, James's change reflects another danger of the outside world, its transformative effect on those who leave their community. This is the theme of leaving: the protagonist is lured away from home only to be transformed by the experience, which makes his return to Cape Breton problematic.

In her book Under Eastern Eyes: A Critical Reading of Maritime Fiction (1987), Janice Kulyk Keefer dedicates an entire chapter to a paradigm in Maritime literature that she calls going and staying. Keefer rightly maintains that the economic conditions are the most important cause of out-migration on the east coast, and the fiction from the region reflects this claim. MacLeod's work is no exception. The characters in his stories recognize the harsh conditions inflicted on them by the "punitive land and sea" and greatly desire an escape. His narrator wrestles with the guilt of having to choose between the one parent who wants him to leave and the other who wants him to stay (Keefer, Eastern Eyes 234). Keefer recognizes how important 
family and community are in MacLeod's work, but does not comment on the degree to which the oral traditions of Cape Breton are responsible for the evolution of themes like leaving and returning, or to what end MacLeod puts them.

Sometimes, however, it is not a stranger who arrives to contaminate the community with outside ideas, but a local who returns to contaminate the community with discord. The theme of returning is often accompanied by the fear of pollution in Atlantic Canadian Literature. Douglas states that there are parallels between cultural and bodily boundaries. She writes, "The threatened boundaries of their body politic would be well mirrored in their care for the integrity, unity and purity of the physical body." (Douglas 124). She also states, "Anything issuing from the body is never to be re-admitted, but strictly avoided. The most dangerous pollution is for anything which has once emerged gaining re-entry." (Douglas 123). In Barometer Rising (1941), and Each Man's Son (1951), Hugh MacLennan takes a local character changed by his experiences abroad and reintroduces him to his hometown. MacLennan raises the tension level of the story by developing, in the mind of this character, the crisis that will ensue when he returns. As local characters also anticipate his return, the tension continues to build. The disruption caused by the returning local can lead to physical violence, as in the case of Archie MacNeil, the boxer in Each Man's Son.

Alternatively, the disruption can be less physical and more emotional, as in the case of Angus, the lawyer in Alistair MacLeod's short story "The Return" (1971). Either way, it is the impact of the external world on the community that is of utmost importance. In "The Return," Angus decides to take his family back home to Cape Breton. His enthusiasm soon wavers amid his wife's reluctance to arrive and his father's cool reception. Although his family loves him deeply, Angus must face the lingering resentment generated by his adolescent decision to leave. 
His white-collar profession in a large metropolitan city sets him apart from the blue-collar miners in his hometown. Because of his partnership with his father-in-law, his own father sees him as a kept man:

"I know, I've tried, I've wanted to, but it's different in Montreal, you know."

"Yes, I guess so. I just never figured it would be like this. It seems so far away and we get old so quickly and a man always feels a certain way about his oldest son. I guess in some ways it is a good thing we don't all go to school. I could never see myself being owned by my woman's family." (MacLeod, Island 85)

Although education is depicted as a partial threat to local culture, it is the connection to urban environments and gender roles that are worth noting. MacLeod's characters attempt to define gender boundaries throughout the story. In one corner, there is the masculine space that is this rural Cape Breton mining town; in the other corner, there is the feminine space that is urban Montreal. Leaving Cape Breton to live and work in Montreal has somehow softened Angus in the mind of his father. Douglas confirms this prevailing attitude: "All power is thought of on the model of sexual energy. Femininity is only dangerous to men as masculinity is to women.[...] There is a strongly held belief that contacts with women weaken male strength." (Douglas 146147). The conclusion the reader must make is that living in an urban environment can be a transformative experience, emasculating those who, like Angus, leave the protection of their traditional rural home.

During Alex's visit to the mine, his grandfather smears his face with coal dust. Like the bloodying of a first time hunter, the blackening of his face with coal dust is a definite rite of 
passage into male space (MacLeod, Island 93). In a variety of cultures, a boy's transition into manhood is not complete unless he performs such a rite: "The rituals enact the form of social relations and in giving these relations visible expression they enable people to know their own society. The rituals work upon the body politic through the symbolic medium of the physical body." (Douglas 128). The grandfather attempts to initiate him into the masculine space unavailable to him in Montreal. Alex is surprised to find that the dust is not gritty but fine like his mother's powder. How did he know what his mother's powder was like? Alex is obviously curious about gender spaces but cannot find a male equivalent to his mother's boudoir.

It is the physical nature of the miners, the sheer size of these men and their energetic labour that defines masculine space. The professional world of Montreal lacks this simple, physical gravity. In an interview with Shelagh Rogers, MacLeod says,

"I know when they closed the mines in Cape Breton here a lot of men said that they missed the camaraderie because it's an all male world. That's probably not highly recommended but it's a physical world and it's an all male world in a lot of the old Celtic communities and the same was true here." (Guilford 19)

After blackening Alex's face his grandfather gives him a powerful embrace, a symbolic recognition that Alex is now a man. Behaving more like a protective mother rather than an encouraging father, Angus interjects and shouts, “"What are you doing? Let him go! He'll suffocate."' (MacLeod, Island 94). Not only is Angus seen as having been emasculated, he has also become a drag on his son's entrance into manhood. The miners leave him behind and only Alex enters the showers for what amounts to a ritual cleansing. The shower could be read as somehow negating the earlier blacking with coal dust but this does not seem to be MacLeod's intention. In the all-male shower room, Alex comes to know that there are indeed gender- 
specific spaces. Douglas believes that the role of ritual is twofold: to clearly mark societal boundaries and thereby prevent transgression and pollution or to neutralize the pollution from those transgressions that have already taken place. Ritual bathing was an easy, symbolic means by which pollution could be eliminated in men (Douglas 125).

There is no rational explanation for how it is that the simple act of bathing could remove pollution. Attempting to wash away pollution is an attempt to restore order by removing anomalous material. Anomalies reside at the margins of the known order, therefore, they are considered dangerous. In magical terms, they are dangerous because the nature of their power is not well defined. To come into contact with that which is anomalous is to risk being contaminated by its power. This implies simple causal reasoning, as does the belief that one could easily wash away such pollution.

In another part of the story, the boundaries delineating gender spaces have shrunk down to their most essential characteristic, sexual behaviour. A local farmer invites Alex and his cousins to witness the controlled insemination of local cattle. He leads a very large bull from the barn to a waiting cow and it proceeds to mount. Alex describes the scene as both "beautiful and terrible" and he knows he will somehow not be able to tell his mother. When the farmer's wife discovers her husband's antics, she chastises him. He nods in agreement but secretly gives the boys a look that "as it excludes the woman simultaneously includes us in something I know and feel but cannot understand." (MacLeod, Island 90-91). For the farmer, gender is a matter as simple as the mating habits of livestock. Like the miners, his is a world where gender roles are clearly traditional. Macleod suggests that the outside world complicated matters; for traditional roles are undervalued, and the boundaries between genders are blurred. 
In the story "In the Fall" (1973), a drover named MacRae loads a horse onto the back of a truck containing an enormous white bull. The horse belongs to a Cape Breton coal miner who rescued it from certain death in the mine. The animal has since repaid his rescuer by waiting for him when he had passed out in a bootlegger's cabin during the coldest night of the year. As a result, the miner has grown deeply attached to it. Money is scarce, however, and if his family is to survive the coming winter, they must sell off the aging animal. The harsh conditions in the region define one's relationship to the land, permitting only the barest of essentials and for this, one must make sacrifices. MacLeod plays with the idea that a character negotiates with the land for the right to live. In the short story "The Vastness of the Dark," the characters regarded the land as a malevolent spirit demanding appeasement. As for "In the Fall," life is pared to the bone for the purpose of survival. The narrator perceives a natural order to which he and all other characters must surrender. The mother, and eventually the father, realizes that the cutting out of all non-essentials, even a loyal and once useful animal, is obligatory.

There are more than economic considerations involved in such a sacrifice. Even the boy, David, realizes this on some level. All the male characters in the story have an emotional attachment to the horse. The same cannot be said of the mother, however, and the surrendering of the horse amounts to a compromise of masculine space. In David's mind, a sacrifice of equal value must now be made of feminine space. This is why David enters the chicken coop and hacks the capons to pieces. David's actions seem to be an attempt to restore balance. In terms of magical thinking, this makes sense. Capons are of course castrated roosters, in no better way could MacLeod restore masculine space than by having these symbols of imposed sexual constraint destroyed. 
The family has made personal sacrifices to maintain their harmonious relationship with the environment, which is in sharp contrast with the modern world that has neglected to do to the same. In the first couple of paragraphs, MacLeod illustrates how disharmonious the modern world has become with his depiction of the sea:

Now it is roiled and angry, and almost anguished; hurling up the brown dirty balls of scudding foam, the sticks of pulpwood from some lonely freighter, the caps of unknown men, buoys from mangled fishing nets and the inevitable bottles that contain no messages. And always also the shreds of blackened and stringy seaweed that it has ripped and torn from its own lower regions, as if this is the season for self-mutilation - the pulling out of the secret, private, unseen hair. (MacLeod, Island 99)

The language suggests that there is nothing meaningful in this relationship with the sea. The "caps of unknown men" and the "bottles that contain no messages" point to anonymity and emptiness, which characterizes modern man's relationship to the environment. Even if it is powerful, the description is far from picturesque. The sea rends itself in its effort to cast out evidence of occupation and exploitation. Phrases such as "the season of self-mutilation" and "the pulling out of secret, private, unseen hair" suggest the sea has become a metaphor for Cape Breton attempting to purge itself of foreign pollution.

In the story "The Lost Salt Gift of Blood" (1974), the narrator returns to Newfoundland after a ten-year absence. He stays with an elderly couple who are raising a young boy named John. What the reader discovers through the course of the story is that the boy is the narrator's son. John's father was one of those "bright graduate students" who came to Newfoundland to catalogue local folklore and superstitions. While conducting his research, he stayed with the 
couple and began a relationship with their daughter, resulting in an unplanned pregnancy. The narrator, as his sexual misconduct implies, is another example of the sexual threat posed by the outsider. In addition, MacLeod makes it clear that John's mother was attracted to his father because he was "from away," for as soon as she can, she leaves Newfoundland for Toronto and marries a man there (MacLeod, Island 134).

John's connection to this place is a very natural one. He is an accomplished fisherman and has a number of lobster traps with catches that rival those of the local men. He has a close relationship with his grandparents and possesses a sense of belonging that neither his father nor mother seemed to possess. This scenario, the son finding a place denied the father, has appeared in other MacLeod stories. The children, through their relationship with their grandparents, are the ones who rediscover their roots. By becoming a fisherman and remaining in Newfoundland, John preserves local traditions while serving as a holdout against modernity. All of them thrive because John rescues the family's centuries-long connection with the sea. The stone he hands to his father upon his departure symbolizes this extraordinary connection: "It has been worn smooth and polished by the unrelenting restlessness of the sea, and buffed and burnished by the gravelled sand. All of its inadequacies have been removed, and it glows with the lustre of near perfection." (MacLeod, Island 140). The sea has shaped John, polishing his character until his finest qualities shine forth, just as it has done to the culture in the region. As the father departs from Newfoundland, leaving his son behind, he finds comfort in the knowledge that John is better off in the life he has built with his grandparents. Beneath this sad, sweet tale is a moral found in many of MacLeod's stories. Maintaining a close relationship with the geography in which one's culture is rooted is essential to an individual's identity and the survival of a people. 
In "The Closing Down of Summer" (1976), the narrator is an aging miner who, along with the rest of the MacKinnon crew, travels anywhere in the world his company needs him. They have just spent the unusually hot and dry summer waiting for the call to their next assignment in South Africa. The narrator is in his senior years, and he expects that this will be his last trip. As summer draws to a close, the storms of autumn are not long off, and he reminisces about the years he and his crew have worked in the mines. The hot and dry summer that precedes the autumn storms mirrors his anxious anticipation of impending death. As in other stories, MacLeod connects his character's lives with seasonal rhythms. His use of imagery elsewhere in the story supports this claim. The "spirited trout" that are "electrically filled with movement" in the spring are in sharp contrast with those in the autumn that are "floating dead," their bodies covered with "fat grey parasites." Obviously, spring is the season associated with renewed life and autumn is associated with death and dying. What is most striking about the above quotation is that the fish have died because their once healthy bodies have become infested with parasites, which becomes a metaphor for the way an outside multinational such as the mining firm, Renco Development, can drain away vital aspects of the community's social relationships.

The casualties of the new global economy are, of course, family and culture. These men are scattered about the world in the pursuit of a living, carrying on long distance relationships that make most forms of intimacy impossible. They have become distant, disembodied voices as immaterial as the forms of payment that they send home to their wives and families:

It is difficult to explain to my wife such things, and we have grown more and more apart with the passage of years. Meeting infrequently now almost as shy strangers, communicating mostly over vast distances through ineffectual saynothing letters or cheques that substitute money for what once was conceived as 
love. Sometimes the cheques do not even come from me, for in the developing African nations the political situation is often uncertain and North American money is sometimes suddenly and almost whimsically "frozen" or "nationalized," making it impossible to withdraw or remove. In times and places such of such uneasiness, shaft crews such as ours often receive little or no actual money, only slips of paper to show our earnings, which are deposited in the metropolitan banks of New York or Toronto or London and from which our families are issued monthly cheques. (MacLeod, Island 192)

MacLeod implies that they have become strangers to their own people, perhaps a new kind of outsider. Globalization not only disrupts the local economy but displaces organic groupings such as the family and community. These men are home barely long enough to father children and certainly not long enough to be a male role model to them:

Yet I was never home for the birth of any of my children, only for their fathering. I was not home when two of them died so shortly after birth, and I have not been home to participate or to share in many of the youthful accomplishments of the other five. I have attended few parents' nights or eighth-grade graduations or father-and-son hockey banquets, and broken tricycle wheels and dolls with crippled limbs have been mended by other hands than mine. (MacLeod, Island 193)

MacLeod leaves little doubt that the new economy is affecting the culture in negative ways. Not only do the current forms of employment make the preservation of their culture difficult but also a more traditional means of earning a living is no longer a viable option for them: 
Out of the flatness of the sea we can see the fishermen going about their work. They do not make much money any more and few of them take it seriously. They say that the grounds have been over-fished by the huge factory fleets from Russia, Spain and Portugal. (MacLeod, Island 186)

Obviously, the nature of work is changing for the miners and their children's education is affected: they learn but a few Gaelic words in the classroom, and it is the government that funds this so-called "Celtic Revival" (MacLeod, Island 195). These same children will later attend universities and pursue professional careers for themselves in distant cities, moving further and further away from the traditional ways of their people.

In another section of the story, the narrator reflects upon his religious beliefs, which his children seem to think are superstitious. A life spent in continuous danger has led to some magical practices: traditional religious regalia have become talismans intended to protect the miners from accidents:

As we have become older it seems we have become strangely more religious in ways that border on superstition. We will take with us worn family rosaries and faded charms, and loop ancestral medals and crosses of delicate worn fragility around our scar-lashed necks and about the thickness of our wrists, seemingly unaware of whatever irony they might project. This, too, seems but a further longing for the past, far removed from the "rational" approaches to religion that we sometimes encounter in our children. (MacLeod, Island 206)

MacLeod's interpretation of magical thinking is much the same as the folklorists collecting material in the Atlantic region. Edith Fowke, for instance, claims that the superstitious practices of miners are a response to the uncertain conditions they face in their work, a very Malinowskian 
view. Perhaps MacLeod assimilated this view when he conducted his own study of regional folklore. Fowke was the pre-eminent folklorist at the time he was writing his stories.

Summer in Cape Breton is the setting for a young man's return home in the story "The Road to Rankin's Point" (1976). For centuries, the MacCrimmons have occupied Rankin's Point but most family members have now moved away. They have left their home for better jobs and easier lives in the cities of the Canadian interior. The young man, Calum, has recently left his job in Ontario to join his grandmother as the sole occupants of Rankin's Point. She is very old, however, and he is terminally ill. As he reflects upon his physical condition, the decline of his family and his people drifts in and out of his thoughts.

There are dangers associated with leaving home. Calum knows it, and at one point, he says this about the outside world, "'It is a big, fast, brutal road that leads into the world on this July day and there is no longer any St. Christopher to be a patron saint of travelers."' (MacLeod, Island 145). His impression is that his time away has changed him. It is as though being away from the protective borders of his community has jeopardized his health. On one occasion, he likens his return home to the return of the salmon: "I have returned now, I think, almost as the diseased and polluted salmon to swim for a brief time in the clear water of my earlier stream. The returning salmon knows of no 'cure' for the termination of his own life."' (MacLeod, Island 165). The quotation leaves little doubt as to the implication: Calum's time away has led to his poisoning, just as the salmon's time away led to their poisoning. Calum refers to his disease, presumably leukemia, as poisoned blood (MacLeod, Island 148). The use of such words as "polluted" and "diseased" are significant. In this case, it serves as a metaphor for the community in crisis. According to Douglas, the disorder expected to follow such a transgression of societal boundaries can translate into concern for the body and bodily pollution. MacLeod, through 
Calum, is attempting to draw a comparison between the effects of cancer on the body with the effects of urbanism and global economics on the body politic.

MacLeod uses pastoral imagery to impress upon his readers the purity and integrity of this region and its culture. The agricultural references that also appear in the story further support the idea that a form of pollution is at work:

For decades my grandmother has been concerned about the purity and wellbeing of these sheep. She has worried about strange rams interbreeding and diluting her "stock." And she has worried about young dogs wild with spring and bloodlust running them over the cliffs to sea-washed deaths. Now there is no need to worry. All the other flocks and dogs from the fallen houses have gone, and it is only her sheep whose bleating cries reverberate across these high cleansed hills.

At the road's end I stop to slide back the poles of the old gate before the final entrance to her yard. As I bend, the blood bursts from my nostrils, splashing scarletly upon my shoes, and there is a dizzying lightness bordering on black within my head. (MacLeod, Island 152)

This herd of sheep, whose pedigree is jealously guarded by his grandmother, alludes metaphorically to Calum's family, whose culture is guarded by the previous generation. His description of his own physical condition follows closely after the description of his grandmother's flocks and the fallen houses. This intentional juxtaposition cannot be missed, and it supports the idea that pollution anxieties are involved here. Calum, however, does not stop there:

Almost all my grandmother's animals are descended from livestock that has been here for a long, long time and over the years they have taken on distinctive 
colourings and characteristics that are all their own. [...] They have always held their heads high when drawing even the heaviest loads and have been perfectly in step with each other, their hoofbeats falling in unison through the regulated choreography of their fiercely inbred generations.[...] For years they have refused to eat any hay except that grown upon this hilly farm; as if smelling and tasting within their own urine, manure and sweat. As if they were part of some great ecological plan, converting themselves into hay and the hay in turn into their wine-dapple-sun-strong selves. (MacLeod, Island 153)

Through long centuries, they have become one with this place, following its natural rhythms, their flesh becoming inseparable from the land that sustains it. There is a delicate balance, "some great ecological plan" that could easily be undone if the "fiercely inbred generations" should leave the land that nurtured them. This is the strongest evidence that MacLeod imagines the Highlanders' connection to the land to be close to indigenous. With this established, the loss of Highland culture becomes synonymous with the corruption of nature.

The idea that urbanism and the global economy are somehow an emasculating or sterilizing force in Cape Breton comes up repeatedly in MacLeod's work. The earlier images of Rankin's Point having become emptied of both livestock and people testify to this. This pattern of death and sterility is completed with the closing of the story. When Calum discovers his grandmother lying dead in the middle of the road he says of Rankin's Point: "For the first time in the centuries since the Scottish immigrations there is no human life at the end of this dark road." (MacLeod, Island 178). 
The ever-present dogs that guard Rankin's Point play a role in all this; they represent the need for watchfulness. Dogs are a real, physical barrier against the outside world but they also symbolize a psychological readiness, the clannish nature of the people:

At "The Little Turn of Sadness" my headlights pick up the eyes of waiting dogs. They are lying in different positions in the middle of the road and their eyes glow out of the darkness like highlighted points of a waiting triangle. Red and gleaming they serve as markers and as warnings; somewhat, I think, like signal buoys of the harbour or the lights along an airstrip's edge.

When I leave the car they are glad to see me. He will know what to do, they seem to say. They are dogs who for centuries have been bred for the guiding and guarding of life. They are not the guardians of junkyards or used-car lots or closed-down supermarkets. Not the guardians of steel and stone but of lives as fragile and as uncertain as their own. Running silently to protect the sheep from the crumbling cliff or crouched beside the lamb with the broken leg, they have always worked closely with human masters and have waited for them when faced with problems beyond their strength. Now they are glad that I have come and move toward me. (MacLeod, Island 177-178)

This passage leaves little doubt as to the role of the dogs as sentinels of Rankin's Point. Calum differentiates his dogs from those put to use guarding property in urban centers, for his dogs protect lives. More than any other symbol employed in MacLeod's stories, dogs define the mental boundaries that guard against the modern, outside world.

MacLeod leaves little doubt that the dogs in his stories have a special connection with their owners. Both the folklore and the literature of the Atlantic region contain numerous references to 
dogs with uncanny abilities (Fraser 96). In Jahoda's opinion, this belief in dogs possessing such abilities is the most common of all contemporary superstitions (Jahoda, Superstition 25). Tales of guardian dogs arrived in the new world from the Scottish Highlands; there are numerous stories of soldiers who have fallen in battle and whose dogs have lain down by their side guarding them even in death. In the tale "The Dog of Roslin," one such soldier dies in the fight for Roslin Castle. Out of loyalty, his hound pursued his master's murderer. So fierce was the animal that the soldiers from the opposing side sought out and destroyed the animal. In the nights that followed, the ghost of the dog returned and continued to track his master's foe. In terror of the dog, the murderer died three days later (Briggs 12). Definitely, there is an attempt to anthropomorphize the dog, for he possessed the kind of loyalty and persistence one would expect of a soldier. Both Helen Creighton and Mary Fraser have noted how tales of supernatural dogs have appeared in local folklore.

In contrast to other stories, the seasonal cycles in "The Road to Rankin's Point" do not appear, on the surface, to match the theme. Calum's life and his family's history on Rankin's Point are at an end but rather than juxtapose these events with images of death, MacLeod writes in signs of life and renewal. Calum returns to Rankin's Point in summer when life is in full bloom and he frequently describes the images he sees. The reason for this is that MacLeod wants to emphasize that his is a premature death. As mentioned, MacLeod went to some pains to depict the occupation of Rankin's Point by the Highlanders as close to indigenous. Calum's condition and the departure of the Scottish Highlanders from the island, therefore, are unnatural events.

Nevertheless, MacLeod does not relinquish the symbolism of natural rhythms entirely. The kind of life he writes about is wild, weedy, and out of control. Rank and riotous growth keeps the modern world at bay, but it is also a sign of disintegration: 
The alders lean and hang from the left bank, their sticky buds smearing the car door's sides and leaving stains that will annoy car washer for a long, long time. The wild flowers burst and hang in all their short lived, giddy aromatic profusion. When the tough but delicate red-and-white roses are nudged by the car they cascade and strew their fragile, perfumed petals across its hood even as their thorns scratch the finished lacquer of its sides. (MacLeod, Island 146) Fecundity and sterility are, of course, polar opposites and figure prominently in fertility magic. In magical thinking, that which is green and growing is associated with the good, and that which withers and browns is evil (Woodbridge 152-153). This, however, is an over-generalization. In magical thinking, there is a distinction between controlled or cultured growth and wild, invasive growth. Shakespeare's Hamlet contains a description of the world that is an excellent example:

"'Tis an unweeded garden/ That grows to seed; things rank and gross in nature/ Possess it merely." (Hamlet 1.2.135-137). This distinction is important because, at first glance at least, the lush growth featured in this story seems to contrast with Calum's ailing condition. In truth, however, it does not. It is an unchecked growth made possible because Rankin's Point is depopulated. MacLeod writes, "The road is now a minor intrusion that the wilderness will reclaim." (MacLeod, Island 147). Vegetation invades and grows out of control on Rankin's Point in much the same way as disease rages out of control in Calum's body. 


\section{$\underline{1976-1986}$}

The next story, "To Every Thing There is a Season" (1977), gets its title from the biblical text Ecclesiastes, implying that the stages of man's life are like the seasons of the year. In many of his short stories, MacLeod weds seasonal rhythms with important plot sequences. Events often transpire around the winter or summer solstice. This is a familiar literary device: Woodbridge observed this same practice in the works of Shakespeare. In her book The Scythe of Saturn: Shakespeare and Magical Thinking (1994), Woodbridge states that to coordinate natural rhythms with social events reflects an awareness of magical thinking. It implies an order in which all things are connected. As stated earlier, she cites the belief that all that is green and living is synonymous with the good as an example. The regeneration of life reaffirms the rhythms of nature and ensures the survival of those dependent on them. Signs of disharmony in nature are consequently clues to disharmony in the social order. Woodbridge suggests that this sort of basic reasoning made its way into literature through the transition of folklore and festival into fiction. The point here is that literary works are themselves important sources of magical thinking for Western writers.

In this story, MacLeod focuses on the way natural cycles regulate human lives. This may in fact be an example of reflexivity: MacLeod foregrounds a characteristic of his own writing when he makes seasonal rhythms the theme of this story. In it, the narrator recalls his growing up in Cape Breton and the necessity of relinquishing childhood myths such as Santa Claus, a contemporary example of magical thinking. As he surrenders his belief in Santa, his parents invite him to stay up late and assist in the placement of presents under the tree: 
Yet I am not so much surprised as touched by a pang of loss at being here on the adult side of the world. It is as if I have suddenly moved into another room and heard a door click lastingly behind me. I am jabbed by my own small wound.[...] I look at my sisters, who have crossed this threshold ahead of me and now each day journey farther from their lives as girls. I look at my magic older brother who has come to us this Christmas from half a continent away bringing everything he has and is. (Macleod, Island 217)

The narrator is making the transition from childhood to adulthood, and MacLeod links the traversing of life's stages with seasonal events. The narrator's brother, Neil, has crossed this same threshold. His life, however, is still regulated by natural rhythms. He is able to come home for Christmas only because he works on a freighter, and the shipping season ends in midDecember when the ice begins to form on Lake Ontario. If the lake freezes early, he will have to take the train; if late, he will take a plane because time is short.

Broadening the scope of these natural cycles to encompass the entire Highland culture is the next logical step for MacLeod. Like so many of Cape Breton's young people, Neil has left home for better prospects abroad. His father's closing words "'Every man moves on" not only sums up Neil's particular situation but it also reflects the theme of so much of Atlantic Canadian literature, the theme of leaving. Linking social events to natural rhythms is so commonplace in literature that its significance often escapes notice. To plot events according to such rhythms is to play on the belief that there is some connection between human destiny and the natural world, which is a form of participation.

MacLeod wants his readers to think about natural rhythms and how they order an individual's life. At the beginning of the story, the narrator described the first snowfall on 
Hallowe'en, and how the muffled footsteps of the children reminded him of mummers. This is not the only time MacLeod mentions mummers in one of his stories. A custom in Atlantic Canada, the origins of mumming can be traced back to the British Isles. The tradition, however, can vary from place to place: mumming practices in the Atlantic region resemble those of Cornish and Irish origins (Halpert, "Typology" 46). They are usually benign and celebratory, but some can involve a good deal of rowdiness, even violence. Mumming marks the transition from one year to the next and serves as an outlet for psychosocial anxieties caused by the passage of the seasons. Mumming provides social cohesion by involving community members in a recognizable social function, and it gives them a feeling of control over natural events.

In Atlantic Canadian literature, mummers remind the reader of the sharp division between locals and outsiders. Among mummers, the most popular choice for a costume is the devil. As well, mummer's costumes often resemble authority figures with ties outside the community. One of the best-known stories involving mummers is Alden Nowlan's "Will Ye Let the Mummers In." In the story, a professor and his wife receive a visit from a troop of mummers. The couple are "from away" and Nowlan sets up the scene such that the local residents latent anxieties, concerning outsiders, surface. With their anonymity safe behind their masks, the mummers assault the couple: they knock the husband to the ground and stick a hand under his wife's blouse.

The first paragraph of "To Every Thing There Is a Season" is in italics: presumably, MacLeod wants his readers to keep it in mind. In it, the narrator remarks that his family have been on Cape Breton Island for a very long time. A few lines of this section are worth noting: Yet when I speak on this Christmas 1977, I am not sure how much I speak with the voice of that time or how much in the voice of what I have since become. And 
I am not sure how many liberties I may be taking with the boy I think I was. For

Christmas is a time of both past and present and often the two are imperfectly

blended. As we step into the nowness we often look behind. (MacLeod, Island 209).

This is not just a poetic way of saying memory is highly subjective. Unlike linear methods of marking time, the cyclical nature of the seasons and their holidays requires one to re-engage the past. History and memory are fluid in MacLeod's stories; that is why his characters can have such an intimate relationship with their ancestors. The quotation above reminds the reader that his characters do not merely recall their past; his characters relive their past, making his history more than a vital force in their lives.

When comparing MacLeod's “Second Spring" (1980) with MacLellan's “The Ghost of Broad Cove" one is immediately struck by the features they have in common. In MacLellan's story, a shepherd, John, has recently purchased a ram for his flock and goes out to see how his ram is faring among the sheep. He is horrified to find it lying dead in the field; in its place stood an enormous black ram. Perturbed, John fetches his neighbour Hector to shoot the animal. After a drink or two to fortify his nerves, Hector arrives to find that there is no longer one black ram, but two. Hector then seeks the advice of another neighbour, Flora. When he returns, having had another nip or two, there are three black rams. In his heightened state of awareness, Hector reasons that by aiming for the middle ram he is bound to hit one of them. Of course, he misses and the ram bolts off. It runs behind Flora's barn, snags a pair of her bloomers and makes across the field to where John is sitting, frightening the wits out of him. To his dying day, John was convinced that the figure dressed in women's bloomers must have been the Devil himself (Shaw, Every Song 359-363). 
Despite the humour, the possibility that MacLellan's black ram is the Devil is revealing. The Devil in disguise may be an indication of acute anxiety over pollution. His presence in MacLellan's story elevates concerns for community integrity to that of the level of the soul (Faris 139). The fables of "Jack and the Devil" can also be found throughout Atlantic Canada and they resemble those tales which have survived in the coastal regions of the British Isles (Briggs 211). In the folklore of the Atlantic region, the Devil is often a metaphor for a stranger. Naturally, he is immediately suspect and approached with caution. Through his slick devices, he attempts to ensnare or fool a local character. More often than not, however, the Devil is the one who is fooled (Faris 139). This is certainly the case in the fable "Jack and the Devil" or "Jack Outwits the Devil." In one version a sailor, Jack, must save his soul and that of a shoemaker and tailor from the Devil. Jack has three chances to come up with a task the Devil cannot perform. The tasks may vary from one version to another but the Devil's final challenge is to pump all the water out of the ship. It is a challenge that the Devil takes up all too lightly. For as soon as the he would near completion a wave would splash over the sides and set him to work again (Briggs 634). John wins the day and saves the souls of both his companions. However, the stranger need not be as obvious a character as the devil; he is often an outsider whose exotic ways are both alluring and dangerous (Faris 138).

In "Second Spring" the narrator, inspired by a visiting agricultural technician, adopts a project that involves the breeding of the family cow with a local purebred Ayrshire bull. Along the way, he encounters an escaped bull of questionable lineage: "No formal heritage was visible in the way he looked or the way he moved, and there was nothing like him in any book entitled Standard Breeds of Cattle." (MacLeod, Island 238). "No formal heritage" is a phrase MacLeod repeats throughout the story, emphasizing the importance of bloodlines. The bull's reckless 
disregard for barriers heightens the drama of the cow's violation: "I thought that with his size and speed and the downward grade of the hill he would perhaps jump over it, but instead he merely moved through it as if it did not exist at all." (MacLeod, Island 239). The bull seems to represent an irrepressible force of nature and it is only the reckless intervention of a passer-by, a rather large man that the bull is driven off. "Do you think he got it in?" he asks. To which the narrator replies, "I don't know." (MacLeod, Island 244). All the male members of the community share the concern for the integrity of the cow's bloodline. Throughout the story, they repeat the inquiry, "Did he get it in?" (MacLeod, Island 242-244). Both MacLellan and MacLeod's work are concerned, at one level, with stock integrity, which is not surprising given the fact that theirs is an agricultural community. There is more to it than that however; it is apparent that this is meant to encourage the reader to make comparisons between animal herds and the human community: "It took nine months from conception to birth-'just like people,' as we used to say. 'Cattle are the only animals that take the same length of time."' (MacLeod, Island 232). He makes other comparisons. He remarks how the path he follows to get his cow to the purebred bull is the same one used secretly by Highland lovers as far back as the $1770 \mathrm{~s}$ (MacLeod, Island 237).

From MacLellan to MacLeod there is an unbroken line in the adaptation of folklore to storytelling. MacLeod retained the agrarian metaphors he found in the folktales of men like MacLellan. This tendency to interpret social behaviour in agrarian or naturalistic terms implies a level of simple causal reasoning: if animal herds benefit from vigilance and isolation then the same must be true for human communities. There is more at work than MacLeod's deliberate effort to preserve his people's folkloric traditions and patterns of magical thinking. For his literary purposes, MacLeod requires the images of purity evoked by well maintained livestock 
As Douglas writes, "Purity is the enemy of change, of ambiguity and compromise. Most of us would indeed feel safer if our experience could be hard-set and fixed in form." (Douglas 162). Attempts to preserve purity reflect anxiety over change; the degree to which characters go to maintain purity, parallels the degree to which they feel the crisis wrought by modernity.

In "Second Spring," however, the father debates the usefulness of controlled breeding. At one time, he too kept a purebred Ayrshire bull but saw little benefit in it. A character like the father brings with him a common sense, which contrasts with the idealistic plans of his young son and the Department of Agriculture representative that inspired him. The plan to preserve pure Ayrshire bloodlines is in fact an outside notion intended for the benefit of the Department, which happens to subsidize the only two purebred bulls in the area. The representative who first proposed the idea to the narrator obviously had an ulterior motive, getting their money's worth out of the bulls. In the case of the father, deference to the representative's authority is perhaps well founded and is but another example of the precarious position outsiders hold in relation to the community. This does not mean that MacLeod's characters do not have their own concerns for Highland culture. The father was equally concerned with whether or not the escaped bull 'got it in.'

Here too, MacLeod does not fail to establish the seasonal patterns that background his stories. MacLeod writes of the culling of the herds in late fall: "We would pay attention to the weather and nearly always kill according to the phases of the moon." (MacLeod, Island 223). It was indeed a tradition to kill livestock in this manner, a practice that dates back as far as the ancient Celts. The narrator's cow, Morag, comes into heat during the summer solstice and kicks up quite a fuss in the confines of the barn; her passion mirrors the summer storm. By day's end, the storm has subsided and so has Morag's heat. He has missed his chance. Coincidently, this 
lost opportunity leads to the belated attempt at fertilization and the subsequent accidental insemination by a bull of questionable origin. It is as though his neglect constitutes a violation of natural rhythms and is partially responsible for the project going awry. Such a technique may seem to be of minor importance but they indicate that MacLeod consistently works natural rhythms into his stories.

"Winter Dog" (1981), like so many of the stories in MacLeod's collection, joins the theme of the outsider to the breeding of animals. As the story begins, the narrator is nervously anticipating a phone call that will require him to make the fifteen hundred mile drive back east. It is Christmas morning, and his children rush out of doors to play in the freshly fallen snow. While he watches, the neighbour's dog joins them in play. He recalls his own childhood in Cape Breton and the mail order dog that once saved him from drowning. In response to an advertisement in the local paper, his father purchased a collie. From the beginning, there had been problems with the dog, and it his breeding that is to blame:

He turned out to be no good at all, and no one knew why. Perhaps it was because of the suspected German Shepherd blood. But he could not "get the hang of it." Although we worked him and trained him as we had the other dogs, he always seemed to bring panic instead of order and to make things worse instead of better. (MacLeod, Island 255)

That the collie has somehow been tainted by German shepherd blood cannot be missed. Not only is he difficult to train but he is a real threat to the cattle, biting their legs instead of nipping suggestively. What is worse, he has become so aggressive towards the neighbours that they fear to come near the house. It is no coincidence that the dog is both aggressive and dysfunctional: besides being of mixed blood, the dog comes from the mainland, which draws ridicule from 
locals. Many of them ask, "Is that your Ontario dog?" (MacLeod, Island 255). Nor is it the only time a MacLeod story features a dog with undesirable characteristics intended to resemble those of an outsider. The story "Clearances" also contains a dangerous and unpopular dog.

The narrator explains that the dog's behaviour is something that has come to the attention of the entire community. It has become a threat to the pedigree of local dogs, slipping out at night to spread his seed:

And perhaps there was also the feeling in the community that he was getting more than his share of the breeding: that he travelled farther than other dogs on his nightly forays and that he fought off and injured the other smaller dogs who might compete with him for female favours. Perhaps there was fear that his dominance and undesirable characteristics did not bode well for future generations. (MacLeod, Island 268)

The emphasis on his aggressive sexuality and predatory nature reveals the extent of the community's anxiety. So unfavourable is local opinion of the dog that the narrator's father arranges to have him shot by one of the neighbours, an image that is powerful, frightening, and potentially provocative.

"The Tuning of Perfection" (1984) contains some folkloric material and a good deal about the loss of Highland culture. This story is about an old but still vigorous man living alone on a mountain in Cape Breton. Throughout the story, he reflects upon his marriage, the death of his wife and son during childbirth, and the loss of traditional values. Gilleasbuig, or Archibald as he is known by his family, has roots that go back to the Isle of Skye. His great-grandfather left his violent past behind in Scotland when he departed for the New World. He is reputed to have built his Cape Breton home high on the mountain where he could "see any potential enemies before 
they could see him." (MacLeod, Island 272). Archie has an extensive reputation as a singer, and he is much sought after by folklorists: "Many of the letters in the later years came from the folklorists who had 'discovered' him in the 1960's and for whom he had made various tapes and recordings and he had come to be regarded as "the last of the authentic old-time Gaelic singers." (MacLeod, Island 280). He still receives routine visits from his granddaughter, Sal, who brings him news and relays his phone messages. On this particular day, she informs him that there is a buyer for his mare, and the family may get their chance to perform in Halifax before the Royal Family. A Gaelic concert is being held to commemorate the year of "Scots Around the World." There is much about the character of Archie that is familiar: a singer and handyman living in the Highlands of Cape Breton, it is as though MacLeod had Lauchie MacLellan in mind when he wrote this story. Both men have been the subject of a book on local folklore, and their musical repertoires have made it into text:

He was faithfully recorded in the archives in Sydney and Halifax and Ottawa and his picture had appeared in various scholarly journals; sometimes with the arms of the folklorists around him, sometimes holding one of his horses and sometimes standing beside his shining pickup truck which bore a bumper sticker which read "Suas Leis A' Ghaidlig." Sometimes the articles bore titles such as "Cape Breton Singer: The Last of His Kind" or "Holding Fast on Top of the Mountain" or Mnemonic Devices in the Gaelic Line'- the latter generally being accompanied by a plethora of footnotes. (MacLeod, Island 280)

Certainly, MacLeod would have found MacLellan to be a striking example of a traditional islander. 
The following sentences are from a letter by MacLeod, which is the Forward to John Shaw's collection of MacLellan's material titled A Story in Every Song:

He worked for many years as a carpenter and the windows through which I view the ocean as I write this were once installed by him.[... He was born into an almost totally Gaelic-speaking world and by the time he left he had witnessed and endured tremendous changes of both a cultural and economic nature. (Shaw, Every Song xixii)

Like MacLellan, Archie was born at a time when Gaelic was the dominant language on the west side of the island, and he seems to be struggling with modernity in much the same way. The phrase "he had witnessed and endured tremendous changes of a cultural and economic nature" is significant: they link the two men together in the struggle with modernity.

Not only is Archie a performer, he also resembles the kind of folkloric figure he might sing about, the mournful or pining lover. Archie and his wife met when they were both very young and built their house together. When it was finally finished, they married and moved in:

During the building of their house, they often sang together and the language of their singing was in Gaelic.[...] On clear still days all the people living down along the mountain's side and even below in the valley could hear the banging of their hammers and the youthful power of their voices. (MacLeod, Island 275)

Their happiness, however, was brief. While he was away at a logging camp, she went into labour. She was alone and there were complications: neither she nor the child survived the ordeal. Even after her death, his heart belonged to her. Like the eagles that nest on his mountain, Archie mates for life. Shortly after her death, his brother dies. His wife, Cora, arrived at his door drunk and 
amorous. Archie, however, refused her advances. He thought there was something vulgar in her manner that contrasted sharply with the personality of his late wife.

There are countless examples of lost lovers in the folklore and such laments are found on both sides of the Atlantic. Both MacLellan and Archie have examples in their collections. One song in MacLellan's repertoire, $O$ hi rithill o bha ho, is about parted lovers:

My people look at me with sorrow

Because my love for you is so constant;

But being to me a second cousin

You're young to be my sweetheart.

My relatives look at me with gloom

Since my love for you is lasting;

Till they lay me in my grave

The youth will be my darling.

(Shaw, Every Song 122)

Although the nature of the separation differs from one song to the next, the depth of the young man's sorrow does not. Archie sings the following song in the story:

Over lofty mountains lies

The dwelling place of my love,

One whose heart was always warm,

And whom I loved too dearly.

And behind the wall of stone 
I would recognize your steps,

But how sad I am tonight

Because we're not together.

Still my love you will last

Like the rock beneath the sea,

Just as long as will the waves

That strike against it always

(MacLeod, Island 299)

The theme of cultural disintegration figures prominently in this story. Foremost in Archie's mind is the loss of traditional values. This is evident in Archie's encounter with the concert producer associated with the Halifax concert: he carelessly rearranges his music, putting Archie at odds with his own family who seem to think that appearing on television is more important than maintaining the integrity of their music:

"Anyway, you're on. But we'd like a few changes."

"Changes?"

"Yeah, first of all we'll have to cut them. That was what I was trying to get around to last night. You're only going to be on stage for three or four minutes each night and we'd like to get two songs in. They're too long. The other problem is they're too mournful. Jesus, even the titles, 'My Heart is Heavy,' 'The Drowning of the Men.' Think about it." (MacLeod, Island 301)

To add to the existing tension, a number of other groups from the area audition for the producer, creating fierce competition for the few open slots in the venue. 
Carver, a rough character from the other side of the mountain, leads one of these groups. Even he, however, has lost touch with some of the traditional values that were once important to a man like Archie:

“"That Archibald,' they say, 'no one knows where he gets all them logs, hauls them out with them horses and doesn't seem to disturb anything. Year after year. Treats the mountain as if it were a garden."'

"Mmmm," he said.

"Not like now, eh? We just cut 'em all down. Go in with heavy equipement, tree farmers and loaders and do it all in a day, to hell with tomorrow."

"Yes," said Archibald. "I've noticed." (MacLeod, Island 289)

He is the one who introduces Archie to a buyer for his horse. During their meeting, Archie learns that his mare is going to a breeding farm where it will be kept in a permanent state of pregnancy. When he inquires as to why they would do this, Carver tells him that their water is used to make birth control pills. Archie finds the whole story preposterous. His bewilderment soon turns to horror when he hears that the colts are of no use to the company that manufactures the pills, so they are discarded. MacLeod intends the sale of the mare to symbolize the sale and corruption of Highland culture, like the music slated for the Halifax concert. The wasted colts suggest shortsightedness, indicative of a soulless society in which no act is abhorrent if it serves the market economy. The product itself, which prevents pregnancies, indicates that children and the natural processes which bring them about are undervalued and subverted in that market. If the only relationship one has with nature is mediated by industry, how can traditional cultures such as Archie's survive? Gone is the meaningful connection to the land and the magical means of interpreting one's relationship to it. 
Others, besides Archie, recognize the need for provisions to safeguard their autonomy and traditions. The Department of Highways is responsible for maintaining the roads, except for the lower reaches, which they claim are private and do not fall under their jurisdiction. Even something as mundane as road maintenance becomes a divisive issue:

The Department of Highways was not fussy about the slightly lower reaches of the road, either, and there were always various petitions being circulated, demanding "better service for the tax dollar." Still, whenever the issue of making a "private" section of the road "public" was raised, there were always counterpetitions that circulated and used phrases like "keeping the land of our fathers ours." (MacLeod, Island 274)

That they should think that extending the authority of The Department of Highways, even a little, should constitute a real threat to their sovereignty is a good measure of how serious they are about preserving their way of life. The phrase " keeping the land of our fathers ours" is such a strong statement that it approaches the level of an indigenous claim on the land, a claim that has appeared in other stories, such as "The Road to Rankin's Point" and "The Island."

The theme of cultural disintegration is not unique to MacLeod's work. Writing in Atlantic Canada has consistently addressed the issue of rural decline. Thomas R. Raddall's "Blind MacNair," is such a story, one which folklorist Edith Fowke claims is based on an actual folktale (Fowke, "Blind MacNair" 173). In Raddall's story, there is a singing duel between MacNair and Johnny Hannigan in the fictional town of Shardstown, Nova Scotia. Singing contests of this nature were once a common occurrence, and they have appeared in a number of tales throughout Nova Scotia (Fowke, "Blind MacNair" 173). MacNair's life closely resembles Marius Barbeau's account of Louis Aveugle, an actual figure who wandered the Saguenay singing his songs for 
food (Fowke, "Blind MacNair" 173). Just as important is the fact that Shardstown is depicted as a community in a state of decay:

"The chanteymen have vanished and the tall grass shines where once the shipyards lay under a snow of chips and shavings....People don't sing ballads now. A chantey? Ha! Where's the need - and no sails to haul?" (Fowke, "Blind MacNair" 173)

Raddall's imagery of disintegration resembles that found in some of MacLeod's stories. Material such as "Blind MacNair" illustrate how Atlantic literary themes can be traced back to the region's oral traditions.

Edith Fowke wrote a letter to Raddall asking if he had relied on original sources of folklore for "Blind MacNair." Raddall replied that he did not collect such material himself but relied on Roy MacKenzie's "Ballads and Sea Songs from Nova Scotia" and material recounted to him by William Smith and other sailors (Fowke, "Blind MacNair” 176). Fowke writes: “'Blind MacNair' clearly comes from an indigenous source: the folklore that an author can obtain only through direct contact with elements from his native background in his capacity as a participantmember of a folk community. It also derives partially from borrowed sources - those of the Smith, Hatt and Mackenzie collections." (Fowke, "Blind MacNair" 183). Because of his relationship with MacLellan, MacLeod's proximity to source material is even stronger than that of Raddall's.

Perhaps more than any other story, “As Birds Bring Forth the Sun” (1985) reveals the importance of folklore and magical thinking in MacLeod's work. From start to finish, the story resembles a folktale, and is the best example of how MacLeod has used the structure of folktale in crafting his own stories. The opening lines illustrate this point: "Once there was a family with 
a Highland name who lived beside the sea. And the man had a dog of which he was very fond." (MacLeod, Island 310). In the story, the narrator has returned home to Cape Breton to visit his ailing father. They are all descendents of a Highland fisherman who once found a grey pup that had been abandoned on his doorstep. Curiously, it arrived in a handmade box, which left some to wonder if it had been part of a buidseachd, an evil spell or curse (MacLeod, Island 316). Not long after its arrival, a cart ran over the pup, and many thought it would not survive. The fisherman, however, went to great lengths to save the dog, feeding it milk and sugar and keeping her warm by the stove. It did indeed survive, and it grew to an enormous size, earning the name cu mor glas, the big grey dog.

$\mathrm{Cu}$ is Gaelic for hound, and it is a term still used in reference to the Irish wolfhound, the tallest of all the dog breeds. The $c u$ in MacLeod's story seems to resemble the great hounds of Celtic folklore, like that slain by the Irish hero, Cuchulainn, whose name means "The Hound of Chulann." Chulann was an Ulster smith who kept an enormous dog. Cuchulainn slew the beast in self-defence; to compensate Chulann offered his services as his champion.

There are a number of curses in MacLeod's stories. Some follow families down through the generations, as in the case of "As Birds Bring Forth the Sun." Cursing involves the transference of evil, and it is a desperate act perpetrated by the powerless upon the powerful (Woodbridge 304). One who casts a curse believes that he can offset this imbalance in power by directing negative energy towards his intended victim, altering their fate for the worse (Woodbridge 304).

In "As Birds Bring Forth the Sun," the cursed fate of the fisherman is confirmed. One winter, when she was heavy with pups, the $c u$ mysteriously disappeared. He thought she might have become stranded on a neighbouring island when the ice broke up. The following spring, he 
and his sons were fishing in rough weather and had to seek the safety of a tiny island. When the father stepped ashore, the $c u$ was there to greet him. She jumped up on her hindquarters, nearly knocking him off his feet. Just then, a pack of grey dogs appeared; these were the pups of the $c u$. Misinterpreting their mother's actions, they fell upon him and tore him to pieces. She managed to chase off the pups, but it was too late, the fisherman was dead. The sons make it home with the father's body only to die years later under mysterious circumstances. The youngest, haunted by dreams of the $c u$, walked to a high cliff one morning and slit his throat. The second son died in a pub in Glasgow. In a drunken haze, he thought he saw the pups of the $c u$ and cried out, $c u$ mor glas. A man at another table mistook his cry of "big grey dog" for an insult; he and several other men then beat the second son to death. Ever since, the descendents of this fisherman have, in their dying moments, been pursued by ghostly grey dogs.

At the father's bedside, the narrator discusses this curse with his family: "Even those who are most sceptical, like my oldest brother who has driven here from Montreal, betray themselves by their nervous actions. 'I avoided the Greyhound bus stations in both Montreal and Toronto,' he smiled upon his arrival, and then added, 'Just in case."' (MacLeod, Island 319). Generations of this family have lived in the shadow of this curse, even though some of them think themselves too rational to believe in such superstitions. MacLeod touches on a fundamental point: magical thinking is never entirely outgrown, and it may continue to influence decision-making well into adulthood.

A few times in the course of the story, the narrator himself comments on superstitious beliefs. It is as though MacLeod is speaking through this character, presenting such beliefs from the region's perspective, how they are not thought of as something shameful: 
Yet with succeeding generations it seemed the spectre had somehow come to stay and that it had become ours - not in the manner of an unwanted skeleton in the closet from a family's ancient past but more in the manner of something close to a genetic possibility. In the deaths of each generation, the grey dogs were seen by some - by women who were to die in childbirth; by soldiers who went forth to the many wars but did not return; by those who went forth to dangerous feuds or love affairs; by those who answered mysterious midnight messages; by those who swerved on the highway to avoid the real or imagined grey dog and ended in a mass of crumpled steel. (MacLeod, Island 318)

The "close to genetic" claim is the key; it raises such beliefs above the level of entertainment to that of a cultural, even racial, phenomenon. These are not the musings of an ignorant mind but the folkloric legacy of a people. The tone is not apologetic, but proud.

Curses and evil spells also appear in some of the stories of Lauchie MacLellan. One in particular, "The Black Thief," is in the form of a fairy tale. The story is about a king who decides to remarry after the death of his first wife. The new queen is insecure about her future inheritance since the king already has three sons from the previous marriage. One day, a witch comes to visit and convinces the queen that the king's sons will inherit their father's kingdom and toss her into the street. To aid the queen, the witch sends her a gift, an enchanted wand. With the help of the wand, the evil queen puts the three sons under a spell so that they should wander the wide world. With some help from the black thief, the three sons and their wives return to their father's kingdom where they trap and burn the witch. From fear, the queen falls down dead, and they toss her into the flames with the witch (Shaw, Every Song 307-325). 
In another story, "Lauchie's Dream," a similar situation unfolds. A witch, known as the Hag of Toad Pond, convinces the princess' stepmother that she will inherit nothing; instead, her stepdaughter will be sole heir. The witch gives the stepmother a potion made from pond water that can transform the princess into an old hag. Meanwhile the witch places the princess' lover, Ranald, under an evil spell, transforming him into a great dog, the Lean Hound of the Green Wood. With the aid of the witch's half-sister, the Old Hag of the Hallow, the couple perform a series of tasks after which they return to their true form and are married. In MacLellan's tales, and MacLeod's short stories, there are a number of similarities: there is the danger posed by a hidden enemy, a gift that is cursed, and a magical dog. On a deeper level, both tales involve a betrayal by a family member and the subsequent loss of one's legacy. The feeling of betrayal that characters feel when family members leave Cape Breton and the subsequent loss of culture appear frequently in MacLeod's stories, and they may have their origins in the oral tradition (Shaw, Every Song 327-341).

Second sight is a paranormal phenomenon accepted by a good many people today. Vyse has listed it among the most frequently occurring magical beliefs in North America. He looked at Gallup poll results taken between the years 1978-1994 gauging the percentage of Americans who believed in various paranormal phenomena (Vyse 35-41). Foreknowledge (precognition) differs from forerunners. The first implies a supernatural ability on the part of the recipient. The later may simply be a case of simple causal reasoning: an unexplained phenomenon precedes a tragic event, such as mysterious lights before a death, and a relationship is then thought to exist between them.

A good deal of the folklore in the Atlantic region deals with paranormal phenomena. Mary Fraser, a Catholic nun and folklorist, found numerous examples of second sight and forerunners 
in Nova Scotian folklore. In Folklore of Nova Scotia (1931), she claims that the belief in second sight as a family trait is widespread in Nova Scotia and likely came over to Cape Breton with the Scottish Highlanders: "Second sight, da-shealladh in Gaelic, is an authenticated Celtic belief." (Fraser 32). She documented a tale about a man from Fraser Mills who had been out walking one day when he encountered a procession of men carrying a body. He was able to identify all the men in the procession except the corpse. Years later, this man encountered the same procession, this time the real one, and as it turned out the dead man he could not identify had just been killed at that exact location (Fraser 34). Mary Fraser's interpretations of local folklore are questionable, claims Edith Fowke, but her material is genuine (Fowke, Folklore of Canada 116). In MacLeod's story "Vision" (1986), two families compete for lobster on adjacent fishing grounds. The narrator recalls the story of twin brothers, Angus and Alex, who set out in a storm in search of their grandmother's home on the point of Canna. Along the way, they encountered a sinister old woman living alone in a dilapidated house. It turns out the old woman has a secret: she is their true grandmother. Their grandfather, Mac an Amharius, had a previous relationship with his wife's sister during which he developed da shealladh. Some thought it came from reading too many books, while others believed he must have inherited it from his unknown father. The sudden onset and horrific nature of the visions troubled him deeply:

Once he "saw" a storm on the evening of a day that was so calm that no one would believe him. When it came in the evening the boats could not get back and all the men were drowned. And once when he was away with the stallion, he "saw" his mother's house burn down, and when he returned he found it happened on the very night he saw it, and his mother was burned to death. (MacLeod, Island 356) 
A local clergyman claimed that his scandalous affair was to blame for his disturbing visions. Mac an Amharius felt it to be a sign, and he reluctantly agreed with the clergyman to end his relationship with her. The sister was outraged, believing that it was a plot cooked up by the two of them. After their break-up, he begins a relationship with her younger sister. When she and Mac an Amharius marry, the older sister makes an unscheduled appearance: "At the wedding the woman cursed the clergyman until he warned her to be careful and told her to leave the building. She cursed her sister, too, and said, 'You will never be able to give him what I can.'" (MacLeod, Island 357). Of course, the wedded couple were never able to conceive a child of their own. The older sister, however, had conceived twin girls: one died in childbirth but the other lived. During labour, she gouged her own eyes so that she was blind ever-after. Because they thought she was mentally unstable, Mac an Amharius and the younger sister took the child in and raised her as their own.

After Angus and Alex had completed their visit with their adopted grandmother, their grandfather hooked up the horses and gave them a ride back to the boat. Along the way, Mac an Amharius stops at the house of his wife's sister, and the two engage in a heated debate. Weeks later, she dies in a terrible fire; presumably, he had a vision of her death and stopped that night to warn her. Mac an Amharius is not the only one in the family to have possessed second sight. Kenneth MacAllester tells the narrator how his own grandmother is a descendent of a man in Scotland who possessed da shealladh. This man could see the future by holding a magical white stone up to his one blind eye. This ability, however, was more of a curse than a blessing. While in Scotland, this ancestor revealed to the wife of an influential man that her husband was unfaithful. Upon hearing the news, the woman had the man killed. According to another account, he escaped the attempt and made his way to the New World. 
"Vision" is not the first story to include foreknowledge. When in "The Road to Rankin's Point" Calum's family comes to visit, he remarks that they do not look like a people who can foresee their own deaths. His grandmother explains the history of the MacCrimmons:

"The MacCrimmons were said to be given two gifts," she says, "the gift of music and the gift of foreseeing their own deaths. Those gifts are supposed to follow in the bloodline. They are not gifts of the ordinary world." (MacLeod, Island 159)

This would explain why, throughout the story, Calum seems strangely at ease with his condition. His passive acceptance may be a sign that he has foreseen his own death and has come to terms with it. One clue that supports this interpretation is his remark that he is unable to save his grandmother. A moment later, his headlights pick out the contours of her body on the ground (MacLeod, Island 177).

By borrowing both the content and structure of folktales, MacLeod's characters can occupy the same folkloric space as their Highland ancestors, which makes it possible for magical thinking to operate unobtrusively within this story. Understandably then, his characters believe in second sight because they subsist on a rich diet of their own folk-history. Stories of second sight, however, are the most frequently documented by folklorists and did abound in mining communities. Miners and their families took claims of second sight seriously, and the visions of the gifted were thought to be omens of impending disaster. It was not unheard of for workers to refuse to enter a mine upon learning that someone in the community had a vision (Fish 159). More often than not, the ability to foresee the future was considered a mixed blessing for the one who possessed it. Malinowski's research suggests that wherever there is a greater degree of occupational risk for which current technology cannot compensate, an individual will turn to 
superstition as a hedge against uncertainty (Vyse 11). No doubt, there was a great deal of uncertainty involved in fishing the stormy Atlantic or digging in the poorly regulated coalmines of Cape Breton.

$\underline{1988-1999}$

When MacLeod published his short fiction collection Island (2000), two previously uncollected stories were made available: "Island" (1988), and "Clearances" (1999). As for the first story, "Island," it was a new direction for MacLeod. In earlier works, wounded or displaced male characters witnessed the effects of technology and global economics on Cape Breton culture. In "Island," the protagonist is an unmarried woman, which is itself unusual for MacLeod. MacLeod's stories frequently include strong women, but this is the first time one has usurped a traditional male role: others only longed for the opportunity. In "The Boat" (1968), it was the narrator's mother, not the father, who valued the traditional fisherman's life. She envied her brothers and the other local fisherman, and she chastised her son for choosing education over assisting his father on the boat. Nevertheless, MacLeod leaves no doubt that the protagonist of "Island" is a sort of male substitute. Her real name is Agnes, but the clerk who filled out her birth certificate recorded her name as Angus (MacLeod, Island 373). When her father suffers an injury and can no longer tend the lighthouse alone, she takes over his duties and adorns herself in her father's work clothes. When both her parents died, she became the sole occupant of the tiny island and assumed operation of the lighthouse. Since her initials were the same as her father's, the cheques kept coming. 
When she was a child, she witnessed the last of the great sailing vessels, and watched as technological innovation changed the nature of life on the sea (MacLeod, Island 406). The image MacLeod gives his readers is of a solitary woman standing as a sentinel over the ruins of a once vibrant, masculine universe:

The lobster fisherman had departed at the end of the season leaving very little of themselves behind. She walked among the deserted buildings looking at the few discarded objects, sometimes touching and turning them with her toes: a worn woollen sock, a length of spliced and twisted rope, a rusted knife with a broken blade, tobacco packages with bleached and faded lettering, a rubber boot with a hole in it. It was as if she were walking through the masculine remnants of an abandoned and vanished civilization. (MacLeod, Island 397-398)

As the mainland continues to modernize, MacPhedran's Island disintegrates. Agnes becomes a silent witness to a once masculine culture, and the ghostly caretaker of its artefacts. Over time, she becomes something of a local legend, as MacLeod's depiction of her reveals: "Standing at the edge of the sea in her dishevelled men's clothing and surrounded by snarling dogs, she later realized that she had passed into folklore. She had, without realizing it, become the 'mad woman of the island." (MacLeod, Island 406).

Stories like "The Boat" and "The Return" feature a sharp division between masculine and feminine spaces. In "The Return," Alex recognizes, perhaps for the first time, these rigid gender boundaries. Through him, the reader sees how ritual maintains order by maintaining these boundaries. It is unclear, however, whether MacLeod desires to sidestep controversial gender issues with "Island" or fine-tune his use of magical thinking. At first, it seems that MacLeod connects the collapse of the island's culture with its feminization. Upon closer examination, 
however, the island is not feminized but emasculated. Gradually, all male characters vacate the island. Agnes's father passes away, and her brother is unfit for a life of isolation. The island's lighthouse wharf, once used by local fishermen, now lies in ruins: "The Government authorities built a splendid new wharf and the spring fishermen no longer came to inhabit the shanties, which began to fall into disrepair, their doors banging in the wind and the shingle flying from their roofs." (MacLeod, Island 405). In the case of "Island," the loss of masculinity no longer accompanies an increase in femininity, as it did in "The Return."

MacLeod depicts technology as a dis-gendering force, sterilizing the island and its culture. Ultimately, technology replaces Agnes as well. The same authorities that built the wharf arrive to inform her that they intend to automate the lighthouse, and she will have to leave the island (MacLeod, Island 407). An even earlier survey of the island by Agnes revealed evidence of sterility and decay. Vast numbers of dried cattails blanket stretches of the shore (MacLeod, Island 373) and it was also possible to find the skeletal remains of shipwrecked sailors who had been stranded on the island (MacLeod, Island 375). The events of Agnes's life also reflect a degree of sterility. As a young woman, she had given birth to a daughter but she went to live with her aunt on the mainland. A later attempt to conceive a child with a group of mackerel fisherman ended in failure, enhancing the atmosphere of infertility: "One summer she realized with a shock that her child-bearing days were over and that that part of her life was past." (MacLeod, Island 406).

The decline of fertility on the island parallels the decline of social order. Macleod's switch to images of sterility links the island's decline with a loss of essence, a very magical approach. Woodbridge identifies the same kind of approach in the Shakespeare's plays. The play Macbeth is about the decline of a just kingship into tyranny. Images of sterility abound in the play: events 
take place on a barren heath, the Macbeths have no children, and the Lady Macbeth herself calls upon dark forces to unsex her. There is a similar use of imagery in "Island," and MacLeod makes it clear where he lays the blame for both the decline of MacPhedran's and Cape Breton Island. The narrator says of the boat that arrives at the island to automate the facilities, "The men wore tan-coloured uniforms and the Canadian flag flew from the mast." (MacLeod, Island 406407).

The lobster fisherman who gets Agnes pregnant at the beginning of the story could be another example of the exotic outsider, but this does not seem to be what MacLeod intends in this case. The evidence is in the way MacLeod depicts him: he is descended from Highlanders, and he speaks both English and Gaelic. When Agnes's lover first appears on the island, the dogs do not respond in their usual protective manner; instead, they accept him as though he was one of theirs: "Yet even as the boat came into the wharf the dogs seemed to make less fuss than was usual and whatever he said quietened them and caused them to be still." (MacLeod, Island 378). Instead, his relationship with Agnes is like that of Highland lovers who appear in so much of the folklore. Often, in such stories, young lovers meet but their relationship ends with the tragic death of the young man while he is away.

Like earlier stories, there are seasonal observances in "Island." This is visible in the timing of the fishermen's arrival, which is in the spring after the ice thaws, and their departure, which is in the autumn before the freeze. The April arrival of Agnes's lover coincides with the breeding season of the rams. They are set upon the island during the summer months to frustrate their mating habits, a custom that ends as the island is gradually depopulated. The arrival of the rams also foreshadows that of the "aroused" and "frenzied" mackerel fishermen who, later in the story, make their appearance on the island's shore. 
In "Clearances" (1999), the narrator, a descendent of Cape Breton Highlanders, compares the recent exodus of island residents with the original Scottish clearances. He is in his senior years when his second-born son dies unexpectedly after a fall from his roof. The narrator gave a large portion of his property to his daughter-in-law so that she would not want for anything. He did not expect that she would fall in love with another man and move away to Halifax, selling off the property before she left. The narrator must live on a fragment of the land that he once owned, while strangers alter the property with little or no regard for the region's traditions: the "surly" new owners erect a seven-foot fence, and they keep a pit-bull terrier to guard the property (MacLeod, Island 423). These outsiders, with their fence and pit-bull terrier, symbolize the colonization of the region by the mainland's urban space. Both the dog and its owner are depicted as invaders. Dogs, therefore, have a dual purpose in MacLeod's stories, both as a barrier against pollution and as a potential threat of pollution. Irish wolfhounds and border collies are closely associated with the Gaelic people, specifically, the Highlanders of Cape Breton. German shepherds and American pit bulls are, as their names suggests, associated with foreigners.

When the narrator was a young man, he left Cape Breton as a soldier bound for Europe during the Second World War. During one of his furloughs, he visits Scotland. On a train from Glasgow, he meets a Gaelic-speaking shepherd with whom he discusses Canada and the clearances. The manner in which he describes the depopulation of the Highlands resembles the current out-migration from Cape Breton. The shepherd is an elderly man; although most of the other tenants have vacated their holdings, he remains on the land. His situation foreshadows that of the narrator who, in his later years, decides to remain on his own property, a holdout against the Cape Breton's clearances. 
In the present, the narrator waits for the arrival of his other son. He discusses the possibility of clearing the remaining wooded section of his property with a brash young man, known locally as a ruthless clear-cutter and a cheat. Their discussion is interrupted by the arrival of a real estate agent bent on selling off the remaining property to an interested German couple. The narrator feels betrayed when his recently arrived son asks if they might sell off the timber before they sell the land to the Germans, not bothering to ask his father if he truly wants to sell. The narrator is definitely under siege: all the other characters, even his son, are trying to exploit the land for a quick buck with little regard for him and his traditions. This image of being under siege is repeated in the final pages. The narrator and his collie confront the neighbour's escaped pit-bull, and they dig in for a fight:

"Both of us are overmatched here," he thought,[...] He lowered his right hand until his fingertips touched the bristling hair on the dog's neck. A small gesture to give each other courage. And then they both took a step forward at the same time. As the blood roared in his ears, he heard the voice again, "They will be with you until the end." (MacLeod, Island 430-431).

The narrator is keenly aware of what is at stake: if he should leave, he is complicit with the dislocation of his people and the loss of his culture. Like a Highland warrior out of some folktale, he intends to make a stand. Clearly, the outsiders in "Clearances" are no longer mainlanders: they are Americans, Germans, individuals from other countries, rather than central Canada. Globalization has taken over the task of displacing the island's economy and culture, a task begun by federalism back in the nineteenth century.

MacLeod retains those agricultural metaphors in this story as well. The protagonist recalls when he and his late wife were young, and they bred border collies, isolating them during the 
breeding season so they would retain their "specialness" (MacLeod, Island 421). MacLeod links sexual urges and the youthful yearning for adventure with the theme of leaving home. The collies are a metaphor for the young people who are leaving the island: like them, their inner drive leads them away from home, and threatens their culture. The narrator himself was not immune to such drives: as a young man, he left home for the war in Europe because he desired adventure as much as he desired to get away from the poverty of Cape Breton. MacLeod seems to imply that these urges could be redirected; if adventure can be found at home, the problem of out-migration may then be solved. Despite some characteristics of the brash young man, the narrator sympathizes with him: he has found a way to remain in Cape Breton and prosper:

"I'm just trying to make a living," said the young man. "This isn't my recreational area. This is my home. Yours too." He felt a wave of sympathy for the young man, recognizing familiar echoes within his speech. (MacLeod, Island 426).

There is a good deal more emphasis on the politics surrounding economic disintegration in "Clearances" than in the earlier stories; this is obvious from the very beginning of the story. The narrator pulls a woollen blanket over him and recalls how he and his wife sheared the sheep that provided the wool that went into it. They would ship the wool to Condon's Woollen Mill in Charlottetown, Prince Edward Island, and sometime later, newly milled blankets would arrive at their home. Once they visited the mill: "Later his wife was to tell her friends, 'We visited Condon's Woollen Mill on Prince Edward Island,' as if they had visited a religious shrine or monument of historical significance and, he thought, she was probably right." (MacLeod, Island 414). The narrator suggests that Condon's Mill is a regional treasure, but its role in the economy is becoming anachronistic. 
Nothing exemplifies the threat of globalization more than the treatment of the local salmon. The narrator and his family have been stewards of this resource for generations, an obligation he hoped to pass on to his son:

"What about it?" continued his visitor. "Soon the tourists and the Government will have everything. Look what happened to the fishing. Look at the Park to the north. We'll all be living in a wilderness area before we know it."

He was surprised that the young man knew about his salmon nets. For generations they had set the delicate, beautiful nets and they had been a promise for his sons. They had fished under threat that the Government would eliminate such customs as theirs because it was thought to be more beneficial if their few salmon entered the mainland rivers for the benefit of the summer anglers. And the rumours had proven, eventually, to be true. (MacLeod, Island 426)

The young man implies that the depopulation of the north, required to create the Cape Breton Highlands National Park, is comparable to the depopulation of the Scottish Highlands all those centuries ago. The government is restructuring the local economy to increase tourism in the region with no regard for those who continue to earn their living from the land. Here, MacLeod connects the loss of micro-economies to tourism and the government. Even if the government is a villain in this scenario, MacLeod does not let his own people off that easily. As the story illustrates, many locals have already sold out to foreigners. The narrator himself is experiencing a good deal of pressure to sell, even from his own son. 


\section{No Great Mischief}

The novel No Great Mischief (1999) is loosely based on the short story "The Closing Down of Summer" and marks MacLeod's first attempt at long fiction. Like his previous stories, the novel was a slow and methodical process taking him over ten years to complete. His labour was well rewarded: the novel received critical acclaim and won him the IMPAC Dublin Literary Award, the largest prize for literature in the English-speaking world. The same approach that was used to analyse the short stories shall be used in examining the novel. Many of the examples

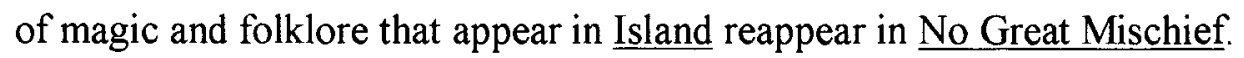

The novel follows the life of the narrator, Alexander MacDonald, a middle-aged dentist who left Cape Breton as a young man to pursue a career. As the novel begins, Alex is visiting his alcoholic brother, Calum, in the city of Toronto. As he nurses him with a generous supply of brandy and beer, they recall the death of their parents, their young manhood in Cape Breton, and the summer they spent at Elliot Lake, Ontario, mining uranium for Renco Development. Both he and his brother are descended from Calum Ruadh, their great-great-great-grandfather who came over from Moidart, Scotland, in August of 1779, with his twelve children, and one loyal dog.

As in the short stories, the disruptive and disorienting effects of globalization are omnipresent in the novel. Alex's description of the urban landscape contrasts with his memories of rural Cape Breton. Along the highway to Toronto, he notices a "pick your own" fruit sign and thinks of the migrant workers who do not pick their own but pick for wages far from their homes in Quebec, New Brunswick, and Mexico. Once, while driving outside of Leamington, his grandmother was shocked to see the tomato crops being ploughed under because the market that created the current glut could not find a better way to deal with the excess. Alex recalls how 
difficult it was for his grandmother to grow tomatoes on the island because the soil was so thin and the season so short. The care she took to grow her few tomatoes highlights the careful, frugal nature of rural life, which stands in contrast with what she witnessed from his car.

MacLeod juxtaposes the images of mass-production and shameless waste with the isolation and alienation of life in Ontario's urban center, Toronto. Alex takes in the sights of the city, the grimy streets and the near squalor conditions of the boarding house where his brother merely survives to feed his addiction. Meanwhile, the anti-nuclear protesters, and their detractors, battle it out on Yonge Street. Someone shouts, "Canada, Love It or Leave It," which raises questions about authority and regional autonomy, questions that pertain to the highland culture of Cape Breton and appear throughout MacLeod's work (MacLeod, Mischief 3).

The novel No Great Mischief contains numerous examples of folklore and magical thinking: there are references to paranormal phenomena, such as forerunners, visions, and even ghosts. Geography remains important as the land continues to wield its mystical hold over the Highlanders. Technology and the global economy, however, always threaten that relationship. As MacLeod broadens the threat from federalism to globalization, he also broadens the impact. He points out that the Highlanders are not the only ones dislocated by globalization; various cultures all around the world are facing a similar situation, losing their connection to the land and watching their culture disintegrate. The mining camp where Alex works is a cosmopolitan place: Highlanders, Quebecois, Irishmen, and African Zulus alike populate the camp. On numerous occasions, MacLeod compares the plight of the Scots in Cape Breton to that of the Zulus and Masai. Not only do they share a common experience of dislocation, but they also share an agricultural base to their societies and a reliance on the natural rhythms that go with it. 
The first example of magical thinking in the novel appears after the accidental drowning of Alex's father, mother, and brother, Colin. They had been crossing the ice that spanned the distance between the lighthouse and their grandparent's home when the ice gave way beneath them. All of them drowned; Colin's body was found, but his parents were never seen again. As a result, Alex and his sister, Catherine, go to live with their grandparents while their brothers move back to the original home of Calum Ruadh. Immediately following the tragedy, rumours began to circulate in the community that their deaths might have been a form of divine justice:

It was generally decided that it was an "act of God," as the insurance companies might term it, although clann Chalum Rhuaidh referred to it as "God's will" and trusted in His Mercy. Some others who had read or misread the Book of Job saw it as an example of God's justice and his punishment, and cast about for reasons. Perhaps since my parents had taken the job on the island they had not gone to church as often as they should have? Perhaps they had engaged in premarital sex in the time before their marriage? Who was to know? Who was to find reasons? (MacLeod, Mischief 54)

Christian or not, this is a characteristic sign of magical thinking. Some members of the community believe that an unseen force is working to procure justice. Alex's parents lost their lives because of their unchristian behaviour, which brought divine retribution upon them, as if they had violated a taboo. The general nature of the accusations brought against Alex's parents are a clue as to what has taken place. In a small way, the MacDonalds have become scapegoats: the community has transferred its evil onto them, represented by the varied and unsubstantiated claims, and their deaths are an opportunity for them to purge their anxiety over imagined violations of God's will. Woodbridge writes, "Expelling evil from a community seems modeled 
on expelling illness from a body.[...] Contagiousness, with which the Renaissance was familiar, fits the idea that evil comes from a neighbour-enemy." (Woodbridge 101). Although enemy may be too strong a word in this case, the point is clearly appropriate to the situation.

When Alex's parents died, neighbours claimed they had witnessed an unnatural occurrence years before the accident: "Others told stories of forerunners; of how they had seen 'lights' out on the ice 'at the exact spot' years before, and of how such harbingers could now be seen as prophecies fulfilled." (MacLeod, Mischief 54). Forerunners also appear in MacLeod's earlier stories, and mysterious lights that forewarn of disaster are mentioned in "Winter Dog": "And over the years we, as others along the coast, had found a lot, although never the pirate chests of gold that were suppose to abound, or the reasons for the mysterious lights that our elders still spoke of and persisted in seeing." (MacLeod, Island 258). Varieties of forerunners are found in the folklore of Cape Breton (Fowke 121-122):

Two young women were sitting up with a child who was dying. It was a beautiful fine night and in that country home everything was quiet. Suddenly the silence was broken by the sound of hammering and sawing in the workshop near by. They looked out; the door was closed, nobody was about. One of them looked into her grandfather's room, from which the sound of his deep regular breathing could be heard distinctly. "Isn't it strange," she said, "there is grandfather sleeping quietly, yet listen to his spirit working out there at the coffin that he'll make only tomorrow." They listened in silence to the uncanny sound. The lunch that was brought in to them could not tempt them. The baby died before morning. And the grandfather made the coffin the next morning as they knew he would. (Fowke, Folklore 121) 
Fowke explains that the forerunner is better understood when the audience is aware that it was the tradition to build the coffin in the most convenient location. People often heard the advance construction before the dreaded event.

The novel's characters assign a good deal of importance to coincidence. After the accident, it just so happened that Alex's grandfather discovers his daughter's purse along the shore. Some thought it peculiar that it should "somehow 'come' to him" (MacLeod, Mischief 57). The grandmother, however, saw nothing peculiar in this since he had been in the habit of walking that route for years. Jung referred to this sort of thing as synchronicity: a coincidence in time of two or more causally unrelated events which have the same or a similar meaning. (Jung, Psyche 441). Jung was attempting to explain parapsychological phenomena in terms of an acausal connection, believing that causal connections were inadequate in trying to explain such phenomena (Zusne 177).

Visions appear in the novel as they had in the short fiction. Visions frequently mark momentous occasions, provide guidance, or warn of impending disasters. Alex tells his sister that on his graduation day his grandfather confessed to having seen his own father twice, in a vision, and in a dream:

He saw him in the vision as a younger man than he was himself - probably, I suppose, because he had been stopped by death and time. He remembered what he looked liked, although, of course, he had never seen him in a physical way. In the vision he unnerved him, but in the dream he consoled him and, I guess, gave him advice as to how he might live his daughter's life and his, for a while. (MacLeod, Mischief 235) 
Visions of the dead are not only the stuff of folklore but have been a popular literary device for centuries. Wilson sites the example of Hamlet and the ghost of his father, who comes as a messenger to warn him of his uncle's treachery (Wilson 116-117). In this case, the vision suggests a possible connection with unseen forces that intercede in the lives of the living.

There are a number of occasions when ghosts are believed by characters to have made an actual appearance. Alex recalls the time his grandfather claimed he saw his own deceased father in the bathroom mirror. He had been drinking heavily, and when the ghost appeared he was so shocked he slipped on the tile floor and banged his head on the tub. Of course, the incident could be dismissed as mere drunkenness. There is, however, a second occasion when his father's spirit does indeed appear to him:

"And one other time, the night after my wife died, he came where I was sleeping and it was probably a dream. He came and stood beside the bed and he had on long woollen underwear, like Stanfields, the kind you wear in the lumber camp in winter. And he bent down and put his hand on my shoulder. 'Look after the little girl,' he said, 'and each of you will then be less alone."' (MacLeod, Island 115)

According to Zusne and Jones, ghosts are one of the most commonly reported supernatural phenomena and certainly the most pervasive, appearing among the folk beliefs and in the literature of peoples all around the world (Zusne 224-225). A 1978 Gallup poll showed that $70 \%$ of Americans believe in the hereafter (Zusne 210). The belief in ghosts represents the unwillingness of people to accept their own mortality, and apparitions support one's hopes for an afterlife, which seems to fit in with this situation. Apparitions as messengers, like that above, 
appear frequently in local folklore throughout the Atlantic region. The most popular work on the phenomenon is Helen Creighton's Bluenose Ghosts.

On at least one occasion, Alex's sister, Catherine, had an unusual experience that resembled a classic encounter with a ghost. One night, she had dinner with her husband and some oil executives in one of Aberdeen's grand hotels. Afterwards, she climbed the stairs to her room where she passed a young woman who uttered something to her in Gaelic. When she looked around the woman was gone. Later that same night, the woman appeared at her bedside and beckoned her to follow. She led Catherine to the hallway where there sat a man in kilt, asleep, with a key in his hand. She turned to close the drapes and when she looked back they were gone (MacLeod, Mischief 159). If this section is reminiscent of the gothic novel, it is perhaps because MacLeod, as a university teacher, specialized in nineteenth century literature. When the dead visit the living in MacLeod's stories, it suggests just how large a role the past plays in the lives of the characters and their culture. David Creelman presents a similar argument in Setting in the East. He writes,

Throughout these texts, mysticism plays a role as superstitions, second sight, and dreams allow the protagonists to connect with the past and converse with forces beyond the grave. Life and death are not represented as binary opposites, but rather as a continuum along which particular individuals can move freely. Protagonists who are able to connect mystically with the past are able to resist and even reshape the present, and so individual identity is no longer anchored exclusively on ambiguous gestures of freedom, but on the movable ground of a community's inherited cultural memory. (Creelman 136) 
This supernatural connection to the past transforms history from a mere collection of dead facts into a living force, influencing and enriching the lives of the characters. This magical tradition, as a key feature of MacLeod's Highland culture, is essential to understanding his fiction.

Some of the most moving passages in the novel are those involving the loyalty of dogs to family members. When Calum Ruadh first left his home in Moidart, his $c u$ lept into the water and swam after him. Alex's sister says, "It was in those dogs to care too much and to try too hard," a phrase that is repeated several times throughout the novel (MacLeod, Mischief 96). As discussed, dogs are omnipresent in MacLeod's stories. In "The Lost Salt Gift of Blood," for example, MacLeod attributes the extraordinary ability to sense disaster to the family dog. When John's mother dies in an automobile accident, the dog somehow knows:

And the dog runned around like he was crazy, moanen and cryen worse than the swiles does out on the ice, and throwen hisself against the walls and jumpen on the table and at the window where the blind fell until we would have to be letten him out. (MacLeod, Island 135)

In No Great Mischief, MacLeod attempts to link the dogs to the supernatural dogs of Gaelic lore; Catherine claims that the place name Glencoe is derived from $\mathrm{Glen} \mathrm{Cu}$, which means the Dog's Glen, after the mythological dogs that once ran there (MacLeod, Island 96).

The belief in an invisible connection between a person and a dog, one that can transcend vast distances, is an example of magical thinking. In the novel, when Alex's parents drown, the family dog moans and scratches at the door, hoping to be released. Afterwards, it crosses over the ice to the lighthouse to remain there until the new keeper arrives; misunderstanding the dog's intentions, he shoots it, and tosses it into the sea. At times, dogs, like ghosts, are mystical messengers. During one of her conversations with her brother, Catherine mentions how the 
natives who fought alongside General Montcalm believed that if they saw a dog in a dream it was a sign that they would win the battle (MacLeod, Mischief 237).

The relationship of the Highlanders to their geography takes on magical proportions in the story. In the novel, Alex's brother tells him that his grandfather used to collect water from an underground spring back home, and he would bring it with him wherever he travelled:

“'Grandpa used to take bottles of it with him,' said my brothers, 'he thought it fuelled sexual desire and was also a cure for arthritis." (MacLeod, Mischief 174). Just like the short story "Vastness of the Dark," the water has a connection to the miners that is sexual in nature: it imparts potency to his grandfather. In the later case, however, it is more explicitly magical, a perfect example of fertility magic. The fact that the grandfather carries some water with him everywhere he goes strengthens the bond between the characters and their home, Cape Breton. It is as though the land magically sustains them; all they need do to maintain their vigour is drink of the waters of their homeland. Male sexual potency is never far removed from allusions to magic or boundary crossings. This same grandfather would get a hard-on when he would cross over into Cape Breton after having been abroad.

In MacLeod's fiction, gender seems to be primarily a matter of biology. There is an attempt in the novel to define masculine space along essentialist lines: it is the heavy gravity of their bodies, their physical and sexual behaviour, which defines their gender. This first appears in the way that Alex's sister found it difficult to accept the conditions under which her brothers lived when they were children:

A certain uneasiness at the development of her own small femininity in the midst of their masculine lives. Almost as if they became more unsure as we all grew 
older. As if their lives and the environment surrounding it were good enough for them but not for her.

Perhaps they were embarrassed by the fact that the bathroom was a bucket or sometimes not even that; that in the hot summer nights, after drinking beer, they would raise their windows and urinate down the outside clapboard walls of their silent house, the steam rising upwards to meet them from the dark. Embarrassed by the fact that they slept with loaded rifles under their beds, and on nights when the moon shone with its full brightness, they would kneel or crouch by their opened windows, straining to sight the antlers of the deer who moved across the fields towards their beleaguered garden. (MacLeod, Mischief 74)

Theirs is an obvious masculine universe, albeit an adolescent one. Apparently, Catherine is uncomfortable with masculine space, and her brothers too have become uncomfortable in her presence. For MacLeod, male space is a rugged, untidy area, one that is threatened by notions of civility: “One day, at noon, my small sister said, 'Don't you have a tablecloth here?' and again, 'Don't you have napkins?" (MacLeod, Mischief 75). This pairing of civility with femininity figures in the development of the grandfather characters as well. One of them is very much like the boys just described. The other is neat, clean, and self-educated, and he is out of place in the masculine space of Ruadh's Point. Civility, cleanliness, and education are imposed on male space as a compromise necessary for feminine companionship. This association of civility and urbanism with femininity is found elsewhere in the novel:

It was true that in Halifax there was a very different kind of life, a life that included movie theatres and music and the possibilities to be found in libraries and laboratories. At times I missed, or imagined that I missed, the theatres and the 
restaurants which I hardly frequented or the discussions with classmates on the subjects of the day. There was a life, I knew, which was not so totally masculine nor dominated by the singleness of one profession. (MacLeod, Mischief 171-172)

As discussed earlier, during the examination of the short stories, MacLeod sees this notion of gender as a product of the agricultural traditions of the region. The pollution anxieties they experience in their description of the unrestrained sexual aggression in animals. The agricultural metaphors MacLeod uses support this idea:

My brothers were embarrassed, in my sister's presence, by the silver-grey rooster energetically servicing the members of his harem, pressing their beaks towards the dust, it seemed, whether they liked it or not, and by the slavering, moaning bull mounting the cow as she offered herself to him in the yard. (MacLeod, Mischief 75)

Alongside this, of course, is the premise that the male sex drive, visibly raw in rural space, is an embarrassment in the more civil and feminine space. So, it is hidden from view, and the differences between genders are minimized. Urban spaces are seen as blurring the lines between genders and violating the boundaries of traditional male space.

The masculine world in which Alex's brothers lived in as boys in Cape Breton is duplicated in the mining camps. Alex turns down a dental research fellowship to work in the mines at Elliot Lake with his family, replacing another MacDonald who died under suspicious circumstances. Following the accident, all the clan Calum Ruadh walked off the site and returned to Cape Breton for the funeral. Only after some negotiations with the superintendent did they decide to return to work. The lives of the men revolve around labour, and at times, physical labour is paired with images of male potency. One scene in particular illustrates this: 
Clann Chalum Ruaidh leaned into the jacklegs at the rock face, the hammering of the wet revolving bits changing the stone into dribbles of grey water which trickled from the holes like constant streams of watery semen or liquid, weak cement. The snaking yellow airhoses trailed behind the jacklegs and the men leaning into them. (MacLeod, Mischief 137)

Even here, in this assuredly male space, masculinity and the natural rhythms associated with it are threatened. One must keep in mind that the mine is a timeless place, unscheduled by the cycles of the sun or the moon: "Underground, beneath the earth's surface, the weather was always the same. The sun never shone and there was no reflection from the moon." (MacLeod, Mischief 141). These natural rhythms are replaced by the artificial rhythms of machines and it is these that order the lives of the miners: "Only the humming of the air compressors and the generators and the sound of moving and revolving steel hammering and grinding into stone. It was easy to loose track of time and space because life underground was dictated, for us, by what happened on the surface." (MacLeod, Mischief 141). These men, like those miners in "The Closing Down of Summer," are far from home, severed from their families, their roots, and their culture. In the bowels of the earth, their sexual libido has been subverted, set to the rhythm of machines, their energy diverted in the service of Renco Development and the global economy. The waste water from the drilling becomes analogous to spilled semen. Douglas writes, "Males are treated as pores through which the precious stuff may ooze out and be lost, the whole system being thereby enfeebled." (Douglas 126).

Once the connection to the land is broken so too is the importance of natural rhythms. MacLeod illustrates this by devoting a fair amount of the text to the power of the moon and then suggests that the connection to this power is broken by urbanization. The moon held an 
important place in early Celtic society. Their calendar, for example, was based on the phases of the moon and not the sun (Herm 144). Natural cycles figure in the timing of community events. The power of the moon figures prominently in the culture of Highland Cape Breton, as does the power of the land. The moon determines the tidal ebb and flow and affects the lives of those who make a living from the sea. In the novel, the moon is said to affect the rhythm of the blood the way it does the tides of the ocean:

At night one can hear the sound of the ocean as it nudges the land. Almost as it is insistently pushing the land farther back. The sound is not of storm but of patient persistence and it is not at all audible in the summer months. Yet now it is as rhythmical as the pulsing of the blood in its governance by the moon. (MacLeod, Mischief 191-192)

This is much more than quaint folklore; it has a practical role to play in the culture of these people:

In the country of the clann Chalum Ruaidh the moon governed the weather and the planting of potatoes and the butchering of animals and, perhaps, the conception and birth of children. "The moon will change tonight," Grandma would say to the overdue, anxious expectant women who were her daughters-inlaw. "After supper we will take a walk, and if God is with us the baby will be born tonight." And even as I think and tell this now, the moon-affected waters are exerting their pressure by the Calum Ruadh's Point. Within the circle of the sun the tides are rising and falling, thrusting and pulling and bringing to bear their quiet but relentless force under the guidance of the moon. (MacLeod, Mischief 140) 
The moon has long been associated with organizing such events and these reflect the agricultural roots of the culture. In matters of conception and birth, the belief in the role of the moon in the timing of such events goes beyond that which can be proven scientifically and approaches the mystical.

Calum's behaviour reveals that such reverence for the moon is in fact a vestige of preChristian beliefs. On the previous page Alex says of Calum, And sometimes at the appearance of the new moon Calum would bow and almost curtsy in the old way and repeat the verses taught to him by the old Calum Ruadh men of the country:

"In the holy name of the Father One

And in the holy name of the Son

In holy name of the spirit Dove

The holy three of Mercy above

Glory forever to thee so bright

Thou moon so white of this very night;

Thouself forever thou dost endure

As the glorious lantern of the poor."

(MacLeod, Mischief 139)

That the moon is accorded a place alongside the Holy Trinity indicates that magical beliefs were not entirely abandoned but incorporated into the new faith. Certainly, MacLeod felt that it is worth dedicating a couple of pages to this belief in the power of the moon. There may be a more subversive reason for the moon's place among the Holy Trinity. In some iconography, Mary, the 
mother of Jesus, is frequently depicted alongside an image of the moon. The moon is a symbol of the mother goddess, and its place in the above piece may have been a clever way of slipping Mary, the Catholic equivalent of the mother goddess, into the otherwise all-male Christian pantheon.

All these mystical connections, to the land, to loyal dogs, to the moon enhance the sense of loss with respect to the displacement of the Highlanders. MacLeod does suggest that this magical relationship to the natural world is altered by a modern, urbanized lifestyle. Life in the city has cut his characters off from the natural world:

The 'lamp of the poor' is hardly visible in urban southwestern [sic] Ontario, although there are many poor who move disjointedly beneath it. And the stars are seldom clearly seen above the pollution of prosperity. (MacLeod, Mischief 192) The last quotation is one of the few times MacLeod, through Alex, links the land, magic, and culture all in one brief section. Not only is the Highlanders' connection to Cape Breton severed when they leave but life in the industrial urban centres makes a comparable connection to geography impossible.

On one other occasion, Catherine too, brings together geography, magic, and the Highland culture. Below, she is contrasting the behaviour of the herring to that of her people:

"The herring," said my sister, "were following patterns as old as time. To me they flow above and beyond whatever we think of as thought. To me they are governed by the moon. And they are faithful in their force. There was an old Gaelic song that grandma used to sing that was composed when the people were leaving Scotland. There was a line in it which said, 'The birds will be back but 
we will not be back,' or something like that. Do you remember it?" (MacLeod, Mischief 227)

What is worth noting is that both the herring and her people are "following patterns as old as time" and these are determined by the moon. These patterns "flow above and beyond" thought, an image that illustrates that this is an instinctive phenomenon beyond the reach of reason. As in the "The Vastness of the Dark," this mysterious power of the moon controls human behaviour. An earlier quotation emphasizes the limitations of technology. MacLeod illustrates this brilliantly in the novel when Alex's sister attempts to have some family photographs altered:

We continued to look at the pictures. "I thought with modern technology," said my sister, "I could separate our parents from these large groups. I took these pictures to a photo studio and asked if it were possible to isolate our parents and then have their individual photographs enlarged. Blown up. I would like to have their pictures on the wall. The photo studio tried, but it would not work. As the photographs became larger the individual features of their faces became more blurred. It was as if in coming closer they became more indistinct. After a while I stopped. I left them with their group. It seemed the only thing to do. (MacLeod, Mischief 240-241)

The group she refers to is the clan Chalum Ruaidh, who are so large that the amateur photographer who took the picture had to stand far back to get them all in. The meaning of the quotation is obvious: despite the power that technology gives one, it cannot preserve identity without distorting it. The individual images are blurred, which makes identification, knowing them, rather difficult. Documentary evidence is hard and inflexible, it is incompatible with culture because it cannot preserve what is important about a people. A culture requires a living 
history with which to interact. This is best illustrated by the way the two grandfathers interpret the history of their people, events like the battle of Culloden Moor and the Plains of Abraham for example. One grandfather holds to the facts; the other prefers a more romantic rendition. The passage also implies that the power of technology carries with it the terrible temptation to use it to alter the past to suit one's own purpose. In a culture that is being displaced by the technological society, this temptation is omnipresent.

Douglas's research into the origins of pollution anxiety was based on observations made of early cultures. MacLeod surely intends his Highlanders to be compared to such peoples. In the novel, Alex continues his conversation with Catherine and compares his people with the Zulus of Africa. The Highlanders, like the Zulus, were not prepared for the impact of modernization on their culture. In his comparison with the Zulus, Alex suggests that technology is at least partly to blame:

The Zulus thought their world would never end. They seemed to be such a tall athletic people. Swaggering and arrogant. They believed in their battle formations and in their songs and in their totems. They believed in their landscape and in their armies of thousands. When they moved across the veldt, singing, people say the ground trembled under the impact of their bare feet. They believed they were invincible and I suppose, in human terms, they were. They just weren't ready for machine guns, and the documentation that followed. (MacLeod, Mischief 231) MacLeod portrays his people as having retained an ancient, nearly indigenous, relationship with their environment, one that may not be understood by those who live in an urban space. This relationship, however, is constantly being eroded. The Scottish diaspora lacks the political institutions of their own nation state to protect its culture. Douglas states that in cultures lacking 
their own specific political boundaries and social institutions, individuals will often focus on matters of genealogy (Douglas 143). This may account for the statement repeated by MacLeod's characters: "always look after your own blood" is a theme repeated throughout MacLeod's work. Alex continues his comparison of the Highlanders with other warrior societies like the Zulus and the Masai:

They follow the cycles of the seasons and pay no heed to boundaries of the parks and game preserves. They were the first, they reason. Unlike the Zulus, they have not yet been confined to certain "homelands" which are really not their homes at all. Perhaps the Masai do not know that others are planning "to do something" with them. "Soon," perhaps. (MacLeod, Mischief 274)

Like the tribesman of Africa, his people also struggle with the political decisions of distant authorities and are mindful of the political boundaries forced upon them. These same authorities are no longer in touch with natural rhythms so they cannot fully understand the relationship of geography to culture. To them, one "homeland" is the same as another. Their experience of physical space may not be as intimate as those whose connection is closer to indigenous and mediated by the magical. 


\section{Conclusion}

Macleod grew up in Inverness County, Cape Breton. Traditionally, this was a resourcebased economy: agriculture and fishing was the mainstay, while forestry and mining supplemented the incomes of many families. Atlantic Canada had been the economic centre until Confederation. Government policy and the railroads transformed the economy in favour of Ontario and Quebec. Although there is evidence that the Atlantic economy had been in decline for more than a decade prior to Confederation, in the minds of Maritimers, Ottawa was to blame for the change in their fortunes. There are plenty of reasons to justify this prevailing attitude: the fisheries are in decline, mining is dead, while tourism and multinational businesses thrive. Atlantic Canada is seen to be under siege from the urbanized centre, its culture exploited and its wealth drained away. To make matters worse, the region's young people are lured away from home by the promise of jobs. These real economic factors are depicted in MacLeod's work while the magical and folkloric material emphasize that this is a culture different from that of the centre, a culture not entirely enthralled by the promises of science and technology. MacLeod makes it clear that folklore and magical thinking are as real a component of his culture as are its economic realities. As the centre comes to dominate the Atlantic region economically, this magical view of the world declines, and it is this magical view that is partially responsible for the Highlanders close connection to their geography. The loss of the magical translates as a partial break in the relationship with the land and a loss of culture.

In "The Tuning of Perfection," the narrator frets over the loss of traditional values and the corruption of his music at the hands of outsiders; even his family sells out. MacLeod is well aware his region and people are being colonized. In the story "The Boat," the mother is 
concerned that her daughters are being lured away by outsiders and outsider values. All of them, eventually, work for an American franchised restaurant. These are not "her people": the men her daughters date are soft and effeminate, typical of an urban lifestyle.

MacLeod illustrates how this colonization by outsiders has led to the disintegration of this culture, which explains the cautious and protective measures of many of his most interesting characters. Fear of the outsider resembles pollution anxieties of the kind Mary Douglas writes about in her book Purity and Danger. This is evident in "The Return" in which the grandfather fears his grandson, Alex, has become polluted during his time in the urban space of Montreal. In MacLeod's work, the outsiders occupy a feminine space, while Highland culture is clearly identified with masculine space. The urban feminization of his grandson is seen as a threat to masculinity. The grandfather, therefore, attempts to cleanse Alex of this contamination by literally showering him.

Other magical approaches include the way characters interpret urban influences as a disease. In "The Road to Rankin's Point," the narrator returns home to die; his disease is closely associated with a modern urban lifestyle. His family have all left and only he and his aging grandmother now occupy the farm. Even the geography of Rankin's Point is depicted as being polluted. The area is going to seed, growing out of control, as is the disease in Calum's body. MacLeod uses a variety of agricultural metaphors to illustrate infestation, loss of essence, and the need for protection. The livestock in his stories are seen as having achieved their strength and vitality from the Highlands and the care of their shepherds, the family's older generation. Not just the livestock, the dogs that guard them also achieved their "specialness" because of such care. 
MacLeod plots events according to natural cycles. In "The Closing Down of Summer," the stages in the life of the narrator match the changing seasons. According to Woodbridge, this is common in western literature and has its origins in magical thinking. Shakespeare used such techniques, and he may have found their source in folklore. MacLeod certainly had first-hand access to traditional folklore in the person of Lauchie MacLellan and probably several other storytellers. This belief in the connection between natural rhythms and human events connects the characters to the land. They have a tendency to mystify their connection to their geography. In "The Vastness of the Dark," the grandfather talks of the hold that the mines have over the miners. Once they drink mine water, they will always come back, he says. In "The Closing Down of Summer," the miners carry water from home wherever in the world they go. They believe it to have therapeutic qualities and to impart sexual potency.

Aside from the above listed examples, there are the paranormal beliefs that appear in MacLeod's stories: second sight, forerunners, and uncanny dogs. According to folklorists, these are legitimate beliefs of the region. In "As Birds Bring Forth the Sun," MacLeod's characters are concerned about the family curse of grey dogs. Although they see such beliefs as superstitious, they cannot help taking precautions against them. MacLeod has in fact made an important observation regarding the nature of magical thinking: regardless of education, one is still inclined to magic beliefs. Vyse states that not only children but also adults retain magical beliefs. MacLeod's work illustrates that magic and superstition are not just interesting topics of conversation but widespread and significant aspects of culture. MacLeod is not the first to have explored the disintegration of traditional culture of the Atlantic region. Raddall's "Blind MacNair" is an earlier example of this trend and it too contains lines about decay of the region's 
culture. Back in the 1920's writers like Frank Parker Day explored the outsider theme and the isolationist tendencies of rural Nova Scotians. He too used local folklore in his work.

MacLeod has linked the decline of the local economy and culture to the global economy and the impact of urbanization. What it comes down to is that MacLeod's stories are in fact modern folktales; like European folktales that have become so much a part of children's literature, his stories warn against strangers and threats to the community. The loss of the magical results in a partial break with the land, for it is the magical that mediates between characters and their geography. The decline of magical traditions, therefore, translates into a decline of the culture. The recent Celtic revival alone cannot rescue MacLeod's culture. The continued loss of economic autonomy and out-migration, in his view, makes a renewed connection to the land difficult if not impossible, and it is this connection that makes for a healthy and stable culture. 


\section{Bibliography}

Abella, Irving, and David Millar, Eds. The Canadian Worker in the Twentieth Century.

Toronto: Oxford University Press, 1978.

Bates, Ernest Sutherland. Ed. The Bible. London: William Heinemann Limited, (no date).

Briggs, Katherine. A Dictionary of British Folktales. 2 vols. Bloomington: Indiana University Press, 1971.

Creelman, David. Setting in the East: Maritime Realist Fiction. Montreal: McGill-Queens University Press, 2003.

Creighton, Helen. Bluenose Ghosts. Toronto: McGraw-Hill Ryerson, 1957.

Creighton, Helen. Folklore of Lunenburg County, Nova Scotia. Ottawa: Department of Resources and Development, 1950.

Creighton, Helen, and Doreen H. Senior. Traditional Songs of Nova Scotia. Toronto: The Ryerson Press, 1950

Davies, Gwendolyn. Studies in Maritime Literary History: 1760-1930. Fredericton: Acadiensis Press, 1991.

Day, Frank Parker. Rockbound. Toronto: University of Toronto Press, 1973.

Douglas, Mary. Purity and Danger: An Analysis of Concepts of Pollution and Taboo. London: Routledge and Kegan Paul Limited, 1966.

Dunn, Charles W. Highland Settler: A Portrait of the Scottish Gael in Nova Scotia. Toronto: University of Toronto Press, 1953.

Faris, James C. "Mumming in an Outport Fishing Settlement: A Description and Suggestions on the Cognitive Complex." Christmas Mummers in Newfoundland: Essays in Anthropology, 
Folklore, and History. Eds. Herbert Halpert and G.M. Story. Toronto: University of Toronto Press, 1969.

Fish, Lydia. “The European Background of American Miners' Beliefs.” Folklore Studies in Honour of Herbert Halpert. Eds. Kenneth S. Goldstein and Neil V. Rosenberg. St Johns: Memorial University of Newfoundland, 1980.

Fowke, Edith. "Blind MacNair: A Canadian Short Story and its Sources." Folklore Studies in Honour of Herbert Halpert. Eds. Kenneth Goldstein and Neil V. Rosenberg. St Johns: Memorial University of Newfoundland, 1980.

Fowke, Edith. Folklore of Canada. Don Mills: McClelland and Stewart Limited, 1976.

Fraser, Mary L. Folklore of Nova Scotia. New York: University of New York Press. (No date).

Frazer, George. The Golden Bough: A Study in Magic and Religion. $3^{\text {rd }}$ ed. 20 vols. New York. MacMillan Company, 1935.

Gruber, Howard E, and J. Jacques Voneche. The Essential Piaget. New York: Basic Books, 1977. Haliburton, Thomas C. The Clockmaker. 1835. Ed. George L. Parker. Ottawa: Carleton University Press, 1995.

Halpert, Herbert. "A Typology of Mumming." Christmas Mumming in Newfoundland: Essays in Anthropology, Folklore, and History. Eds. Herbert Halpert and G.M. Story. Toronto: University of Toronto Press, 1969.

Herm, Gerhard. The Celts: The People Who Came Out of Darkness. New York: St Martin's Press, 1975

Hochbruck, Wolfgang. "Centre and Margin: Literature from the Maritimes.” Down East: Critical Essays on Contemporary Maritime Canadian Literature. Eds. Wolfgang Hochbruck and James O. Taylor. Trier: Wissenschaftlicher Verag Trier, 1996. 
Jahoda, Gustav. Images of Savages: Ancient Roots of Modern Prejudice in Western Culture. New York: Routledge, 1999.

Jahoda, Gustav. The Psychology of Superstition. London: Penguin Books, 1969.

Jung, Carl. "The Structure and Dynamics of the Psyche." The Collected Works of C.G. Jung. 20 vols. Eds. Sir Herbert, Michael Fordham, Gerhard Adler, William McGuire. Princeton: Princeton University Press, 1969

Keefer, Janice Kulyk. "Nova Scotia's Literary Landscape." Down East: Critical Essays on Contemporary Maritime Canadian Literature. Eds. Wolfgang Hochbruch and James O. Taylor. Trier: Wissenscaftlicher Verlag Trier, 1996.

Keefer, Janice Kulyk. Under Eastern Eyes: A Critical Reading of Maritime Fiction. Toronto: University of Toronto Press, 1987.

Lewellen, Ted C. The Anthropology of Globalization: Cultural Anthropology Enters the $21^{\text {st }}$ Century. London: Bergin and Garvey, 2002.

MacDonald, D.R. Eyestone. Wainscott: Pushcart Press, 1988.

McDonald, Criag. "Alistair MacLeod and the Turning of Perfection." Writers on Writing. Online. http://www.modestyarbor.com/macleod.html.

MacDonald, Margaret Read. Ed. The Folklore of World Holidays. Detroit: Gale Research, Inc, 1992.

MacKinnon, Kenneth, Ed. Atlantic Provinces Literature Colloquium Papers. Saint John: University of New Brunswick, 1976.

MacLennan, Hugh. Barometer Rising. Toronto: New Canadian Library, 1989.

MacLennan, Hugh. Each Man's Son. Toronto: New Canadian Library, 2003. 
MacLeod, Alistair. Forward. A Story in Every Song: The Songs and Tales of Lauchie MacLellan. Trans. Ed. John Shaw. Montreal: McGill-Queens University Press, 2000.

Macleod, Alistair. Island: The Collected Stories of Alistair Macleod. Toronto: McClelland and Stewart Ltd, 2000.

MacLeod, Alistair. No Great Mischief. Toronto: McClelland and Stewart Ltd, 1999.

Opie, Iona, and Peter Opie. The Lore and Language of School Children. London: Oxford University Press, 1959.

Piaget, Jean. Language and Thought of the Child. $2^{\text {nd }}$ ed. London: Routledge \& Kegan Paul Limited, 1932.

Rogers, Shelagh. "An Interview With Alistair MacLeod." Alistair MacLeod: Essays on His Works. Ed. Irene Guilford. Toronto: Guernica Editions Inc, 2001.

Shakespeare, William. The Tragedy of Hamlet, Prince of Denmark. Ed. G.R. Hibbard. New York: Oxford, 1987.

Shaw, John. Trans. Ed. A Story in Every Song: The Songs and Tales of Lauchie MacLellan. Montreal: McGill-Queens University Press, 2000.

Shaw, John. Trans. Ed. Tales Until Dawn: The World of a Cape Breton Gaelic Story-Teller, Joe Neil MacNeil. Kingston: McGill-Queen's University Press, 1987.

Sontag, Susan. Illness as Metaphor. New York: Farrar, Straus, and Giroux, 1978.

Thurschwell, Pamela. Literature, Technology and Magical Thinking 1880-1920. Cambridge: Cambridge University Press, 2001.

Hochbruck, Wolfgang and James O. Taylor. Eds. Down East: Critical Essays on Contemporary Maritime Canadian Literature. Trier: Wissenscaftlicher Verlag Trier, 1996. 
Vyse, Stuart A. Believing In Magic: The Psychology of Superstition. Oxford: Oxford University Press, 1997.

Wilson, Anne. Magical Thought in Creative Writing. London: Thimble Press, 1983.

Woodbridge, Linda. The Scythe of Saturn: Shakespeare and Magical Thinking. Chicago: University of Illinois Press, 1994.

Zipes, Jack. The Great Fairy Tale Tradition: From Straparola and Basile to the Brothers Grimm. New York: W.W. Norton and Company, 2001.

Zusne, Leonard and Warren H. Jones. Anomalistic Psychology: A Study of Magical Thinking. Hillside: Lawrence Erlbaum Associates, 1989. 